\title{
The magnitude, timing and abruptness of changes in North African dust deposition over the last 20,000 yr
}

\author{
D. McGee ${ }^{\mathrm{a}, *}$, P.B. deMenocal ${ }^{\text {b,c }}$, G. Winckler ${ }^{\text {b,c }}$, J.B.W. Stuut ${ }^{\text {d,e }}$, L.I. Bradtmiller ${ }^{\mathrm{f}}$ \\ a Department of Earth, Atmospheric and Planetary Sciences, Massachusetts Institute of Technology, Cambridge, MA 02139, USA \\ ${ }^{\mathrm{b}}$ Department of Earth and Environmental Sciences, Columbia University, New York, NY 10025, USA \\ ${ }^{\mathrm{c}}$ Lamont-Doherty Earth Observatory, Palisades, NY 10964, USA \\ ${ }^{\mathrm{d}}$ Royal Netherlands Institute for Sea Research (NIOZ), Texel, The Netherlands \\ e MARUM-Center for Marine Environmental Sciences, University of Bremen, Bremen, Germany \\ ${ }^{\mathrm{f}}$ Department of Environmental Studies, Macalester College, St. Paul, MN 55105, USA
}

\section{A R T I C L E I N F O}

\section{Article history:}

Received 30 October 2012

Received in revised form

27 March 2013

Accepted 30 March 2013

Editor: G. Henderson

Available online 9 May 2013

Keywords:

eolian dust

North Africa

African Humid Period

deglaciation

abrupt change

${ }^{230}$ Th normalization

\begin{abstract}
A B S T R A C T
Reconstructions of eolian dust accumulation in northwest African margin sediments provide important continuous records of past changes in atmospheric circulation and aridity in the region. Existing records indicate dramatic changes in North African dust emissions over the last $20 \mathrm{ka}$, but the limited spatial extent of these records and the lack of high-resolution flux data do not allow us to determine whether changes in dust deposition occurred with similar timing, magnitude and abruptness throughout northwest Africa. Here we present new records from a meridional transect of cores stretching from $31^{\circ} \mathrm{N}$ to $19^{\circ} \mathrm{N}$ along the northwest African margin. By combining grain size endmember modeling with ${ }^{230} \mathrm{Th}$-normalized fluxes for the first time, we are able to document spatial and temporal changes in dust deposition under the North African dust plume throughout the last $20 \mathrm{ka}$. Our results provide quantitative estimates of the magnitude of dust flux changes associated with Heinrich Stadial 1, the Younger Dryas, and the African Humid Period (AHP; $11.7-5 \mathrm{ka}$ ), offering robust targets for model-based estimates of the climatic and biogeochemical impacts of past changes in North African dust emissions. Our data suggest that dust fluxes between 8 and 6 ka were a factor of $\sim 5$ lower than average fluxes during the last $2 \mathrm{ka}$. Using a simple model to estimate the effects of bioturbation on dust input signals, we find that our data are consistent with abrupt, synchronous changes in dust fluxes in all cores at the beginning and end of the AHP. The mean ages of these transitions are $11.8 \pm 0.2 \mathrm{ka}(1 \sigma)$ and $4.9 \pm 0.2 \mathrm{ka}$, respectively.
\end{abstract}

(c) 2013 Elsevier B.V. All rights reserved.

\section{Introduction}

North Africa is the world's largest source of mineral dust to the atmosphere, emitting hundreds of $\mathrm{Tg}\left(10^{12} \mathrm{~g}\right)$ of dust per year (Goudie and Middleton, 2001; Engelstaedter et al., 2006; Ridley et al., 2012). Historical dust emissions from the region appear to sensitively track variations in continental aridity and atmospheric circulation (Prospero and Lamb, 2003; Chiapello et al., 2005; Mukhopadhyay and Kreycik, 2008; Doherty et al., 2012). An estimated $250 \mathrm{Tg}$ of dust per year is transported over the tropical North Atlantic Ocean (TNA) (Ridley et al., 2012), with substantial impacts on precipitation (Miller et al., 2004; Yoshioka et al., 2007), sea surface temperatures (SSTs) (Evan et al., 2009, 2011) and marine biological productivity (Moore et al., 2009). North African dust may also have far-ranging impacts on

\footnotetext{
* Corresponding author. Tel.: +1 617324 3545; fax: +1 6172538630 .

E-mail address: davidmcg@mit.edu (D. McGee).
}

precipitation and radiation balance by providing condensation nuclei for ice clouds (DeMott et al., 1993).

Records of North African dust emissions over the last $20 \mathrm{ka}$ highlight the sensitivity of North African climate to both local summer insolation and high-latitude conditions (deMenocal et al., 2000; Adkins et al., 2006; Tjallingii et al., 2008; Mulitza et al., 2008). Two periods of cold North Atlantic SSTs - Heinrich Stadial 1 and the Younger Dryas (Bard et al., 2000; Shakun et al., 2012) are marked by maximum dust concentrations in offshore sediments (Tjallingii et al., 2008; Mulitza et al., 2008). The early Holocene African Humid Period (AHP; $11.7-5 \mathrm{ka}$ ), a time of high local summer insolation and warm North Atlantic SSTs, is marked by low dust deposition, consistent with records indicating lake expansions and a northward expansion of Sahelian vegetation at this time (Hoelzmann et al., 1998; Gasse, 2000). At the end of the AHP, Ocean Drilling Program (ODP) Site 658C records a doubling of dust fluxes over at most several centuries, followed by a gradual rise in dust fluxes over the last $5 \mathrm{ka}$ paralleling the decline in summer insolation (Adkins et al., 2006). 
Several studies have reconstructed the relative abundance of dust in African margin sediments using endmember modeling of geochemical, grain size or magnetic data (Tjallingii et al., 2008; Mulitza et al., 2008; Itambi et al., 2009). Though these studies corroborate many findings from ODP Site 658C, they suggest that terrigenous sediments in the region are derived from both eolian and hemipelagic sources (Holz et al., 2004; Tjallingii et al., 2008; Mulitza et al., 2008); as a result, the record of total terrigenous flux from ODP Site $685 \mathrm{C}$ may overestimate eolian fluxes and underestimate the amplitude of changes in eolian fluxes due to hemipelagic inputs. Significantly, endmember modeling studies also suggest a gradual end to the AHP, raising the question of whether ODP Site 658C is representative of other regions of North Africa.

Here we present records of eolian and hemipelagic sediment fluxes over the last $20 \mathrm{ka}$ from five sediment cores forming a meridional transect between $31^{\circ} \mathrm{N}$ and $19^{\circ} \mathrm{N}$ along the northwest African margin. This study provides the first records from the region that separate eolian and hemipelagic sediment fluxes using a combination of grain size endmember modeling and ${ }^{230} \mathrm{Th}$-normalization. These records offer new estimates of changes in dust flux associated with deglacial climate changes, the AHP and Late Holocene drying. Carbonate records from these five cores and four additional cores provide a further test of the spatial coherence of past dust flux changes. We model the impact of bioturbation on our records to determine whether dust flux changes occurred with similar abruptness and timing throughout the North African dust plume and to provide age estimates for dust flux changes at the ends of the Younger Dryas and the AHP. Our quantitative estimates of dust fluxes offer targets for models of past dust emissions and efforts to quantify dust-related climate and biogeochemical impacts associated with the LGM, Heinrich events, and the AHP.

\section{Regional setting}

North Africa produces mineral dust throughout the year, with high emissions in boreal winter, spring and summer and a minimum in fall (Engelstaedter et al., 2006; Ridley et al., 2012). Satellite estimates of aerosol optical depth (AOD) highlight two main source regions in the Sahara - one in the Bodéle depression of Niger and Chad, the other in western Mauritania and eastern Mali - as well as a number of smaller sources (Fig. 1) (Prospero et al., 2002). Dust is mobilized by a variety of meteorological conditions, including cold air outbreaks from higher latitudes, surface trade winds (Harmat$\tan$ ), and downward mixing from low level jets in winter, and convective outflows in summer (Chiapello et al., 1995; Engelstaedter et al., 2006; Warren et al., 2007; Williams, 2008; Schepanski et al., 2009; Ridley et al., 2012). In the winter and spring, dust tends to be transported at altitudes below $2 \mathrm{~km}$ toward the southwest within the trade winds, while in the summer dust travels west at altitudes of $3-5 \mathrm{~km}$ in association with easterly waves (Chiapello et al., 1995; Engelstaedter et al., 2006; Huang et al., 2010; Ridley et al., 2012).

Measurements of near-surface airborne dust concentrations (Chiapello et al., 1995) and lithogenic fluxes in sediment traps (Neuer et al., 1997; Ratmeyer et al., 1999; Bory and Newton, 2000) indicate a peak in dust deposition along the northwest African margin in winter and early spring. Airborne dust (Stuut et al., 2005) and dust collected in sediment traps (Ratmeyer et al., 1999) in this region is relatively coarse, with modal grain sizes typically $>10 \mu \mathrm{m}$, suggesting proximal sources. Extensive dune fields near the coast, in particular in western Mauritania and northern Senegal near our southern sites, likely serve as sources of coarse dust (Lancaster et al., 2002). Though dust fluxes at our core sites may primarily reflect winter deposition from local sources, reconstructed dust fluxes at Cape Verde are strongly correlated both

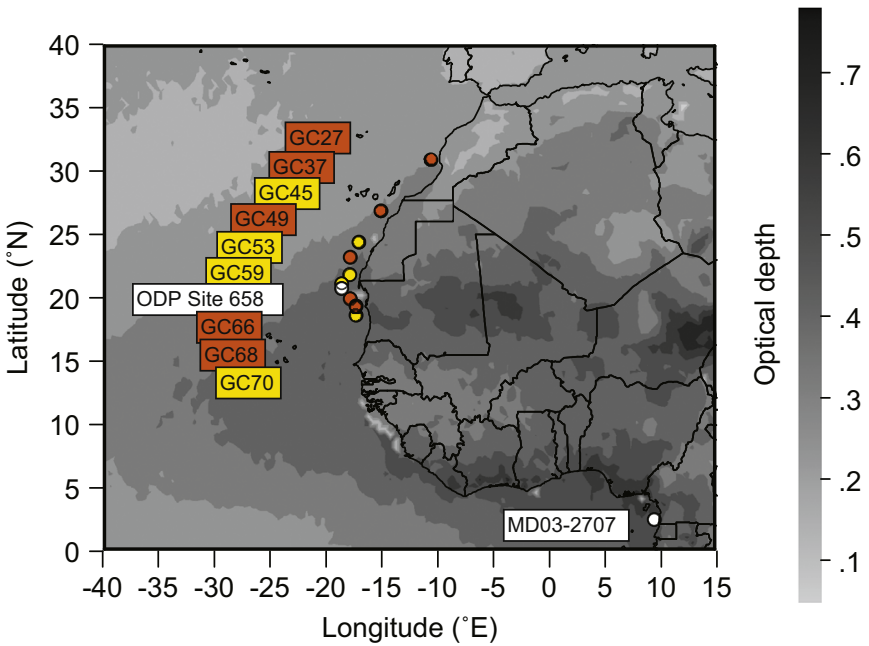

Fig. 1. Map of core sites and satellite-derived aerosol optical depth (AOD) at $555 \mathrm{~nm}$ for 2001-2007. Grain size, U-Th and carbonate data were collected for cores shown in orange; only carbonate data has been collected for cores shown in yellow. Shown in white are the locations of ODP Site 658 (deMenocal et al., 2000; Adkins et al., 2006) and MD03-2707 (Weldeab et al., 2007). The location for GeoB7920-2 (Tjallingii et al., 2008) is the same as that for ODP Site 658. AOD data are from the MISR satellite and were retrieved from the Giovanni online data system, developed and maintained by the NASA GES DISC. (For interpretation of the references to color in this figure legend, the reader is referred to the web version of this article.)

with boundary layer dust concentrations near Barbados (representative of the summer dust plume) and with satellite estimates of mean annual dust optical depth over the TNA (Mukhopadhyay and Kreycik, 2008; Evan and Mukhopadhyay, 2010). These findings suggest that dust fluxes along the northwest African margin are plausibly representative of North African dust emissions over the TNA.

Observational records of African dust emissions show strong interannual- to decadal-scale variability, with dust concentrations in Barbados air and dust fluxes reconstructed from a Cape Verde coral each rising by a factor of $\sim 4$ from the late 1950 s to the early 1980s (Prospero and Lamb, 2003; Mukhopadhyay and Kreycik, 2008). Recent work finds that variations in winter dust emissions are best correlated with the position of the ITCZ over North Africa, with a southerly position associated with increased surface winds over central and western North Africa (Doherty et al., 2012). Precipitation appears to play a relatively minor role in modern interannual variability (Doherty et al., 2012), consistent with the fact that Saharan source areas are perennially dry (Engelstaedter and Washington, 2007a).

Sediments off the northwest African margin show the imprint of the region's dust emissions. The lithogenic fraction of sediments matches the $\mathrm{Sr}$ and $\mathrm{Nd}$ isotope composition of dust source regions in Mauritania, Mali, southern Algeria and Morocco (Grousset et al., 1998; Meyer et al., 2011), regions identified as dominant sources of modern dust transport to the region (Skonieczny et al., 2011; 2013). The quartz content and silt content of northeast tropical Atlantic sediments mimics the shape of the modern dust plume (Kolla et al., 1979; Sarnthein et al., 1981; Holz et al., 2004). Provenance data suggest that the orientation and sources of the dust plume have remained roughly constant over the last $25 \mathrm{ka}$ (Sarnthein et al., 1981; Grousset et al., 1998; Cole et al., 2009).

\section{Core descriptions and chronologies}

The gravity cores used in this study were taken by the $\mathrm{R} / \mathrm{V}$ Oceanus during the 2007 Changing Holocene Environments in the 
Table 1

Core locations, depths and distances from modern and LGM shorelines.

\begin{tabular}{|c|c|c|c|c|c|c|}
\hline Core ID & $\begin{array}{l}\text { Latitude } \\
\left({ }^{\circ}\right)\end{array}$ & $\begin{array}{l}\text { Longitude } \\
\left({ }^{\circ} \mathrm{W}\right)\end{array}$ & $\begin{array}{l}\text { Water depth } \\
\text { (m) }\end{array}$ & $\begin{array}{l}\text { Mean LSR } \\
(\mathrm{cm} / \mathrm{ka})\end{array}$ & $\begin{array}{l}\text { Distance to modern } \\
\text { shoreline } \\
(\mathrm{km})\end{array}$ & $\begin{array}{l}\text { Distance to } 120 \mathrm{~m} \\
\text { isobath } \\
(\mathrm{km})\end{array}$ \\
\hline OC437-7 GC27 & 30.880 & -10.630 & 1258 & 6.1 & 75 & 50 \\
\hline OC437-7 GC37 & 26.816 & -15.118 & 2771 & 9.5 & 90 & 70 \\
\hline OC437-7 GC45 & 24.368 & -17.048 & 1661 & 5.1 & 135 & 40 \\
\hline OC437-7 GC49 & 23.206 & -17.854 & 2303 & 8.6 & 160 & 80 \\
\hline OC437-7 GC53 & 21.798 & -17.872 & 1280 & 10 & 90 & 45 \\
\hline OC437-7 GC59 & 21.131 & -18.590 & 2777 & 11 & 155 & 100 \\
\hline OC437-7 GC66 & 19.944 & -17.860 & 1454 & 22 & 120 & 30 \\
\hline OC437-7 GC68 & 19.363 & -17.282 & 1396 & 11 & 75 & 30 \\
\hline OC437-7 GC70 & 18.647 & -17.323 & 2260 & 19 & 110 & 70 \\
\hline
\end{tabular}

Eastern Tropical Atlantic (CHEETA) cruise (OCE437-7). Cores were taken from the continental slope in water depths of $1258-2777 \mathrm{~m}$ (Table 1; Fig. 1). Core locations are $75-160 \mathrm{~km}$ from the modern shoreline and $30-100 \mathrm{~km}$ from the $120 \mathrm{~m}$ isobath, the approximate location of the LGM shoreline. Cores GC27 and GC66 were taken near the Agadir and Cap Timiris submarine canyons, respectively. Both canyon systems have been active during the last $20 \mathrm{ka}$ (Weaver et al., 1992; Wien et al., 2007; Zuhlsdorff et al., 2007).

Core chronologies were developed from AMS radiocarbon ages on planktonic foraminifera. Most ages were determined on specimens of Globigerina bulloides, but in some intervals mixed planktonic species were used due to low abundance. Though $G$. bulloides was used due to its abundance, this species may provide ages that are 400-600 yr older than Globigerina inflata (deMenocal et al., 2000). The ages used in this study should then be considered maximum estimates. Details of radiocarbon dating and age model construction are further described in the Supplementary Material.

Average linear sedimentation rates (LSRs) vary between 5 and $22 \mathrm{~cm} / \mathrm{kyr}$, with minimum LSRs in GC27 and GC45, maximum LSRs in GC66 and GC70, and intermediate LSRs $(8-11 \mathrm{~cm} / \mathrm{kyr})$ in the remaining cores.

\section{Methods}

\subsection{Biogenic sediment concentrations}

Carbonate was measured in all cores by coulometry at LDEO (Tables S1-S5). Opal was measured in GC37, GC49 and GC68 by alkaline extraction at LDEO and Macalester College according to the method of Mortlock and Froelich (1989). Organic carbon was determined in GC37, GC49 and GC68 by combustion on a subset of samples and was consistently $<2 \%$. The terrigenous fraction of samples from GC37, GC49 and GC68 was calculated as the residual after subtracting the measured carbonate, opal and organic carbon percentages. For GC27 and GC66, terrigenous fraction calculations use the average opal and organic carbon percentages from the nearest core for which measurements were available.

\section{2. $U$, Th isotope measurements}

Sediment fluxes were determined by ${ }^{230} \mathrm{Th}$ normalization in cores GC27, GC37, GC49, GC66 and GC68 (Supplementary Material). Uranium and thorium isotope abundances were determined by isotope dilution using an Axiom single-collector ICP-MS at LDEO following the methods of Anderson and Fleer (1982) and Fleisher and Anderson (2003). Process blanks and replicate samples were processed with each set of samples. All blank values were $<1 \%$ of sample isotope abundances. Variation of eight replicate samples averaged $2.1 \%$ for ${ }^{230} \mathrm{Th}, 5.8 \%$ for ${ }^{232} \mathrm{Th}$, and $4.4 \%$ for ${ }^{238} \mathrm{U}$.

Estimates of ${ }^{230} \mathrm{Th}$ supported by detrital and authigenic $\mathrm{U}$ assume a ${ }^{238} \mathrm{U} /{ }^{232} \mathrm{Th}$ activity ratio of $0.7 \pm 0.1(1 \sigma)$ in detrital minerals (Adkins et al., 2006). Uncertainties reported for ${ }^{230} \mathrm{Th}_{\mathrm{xs}}$ activities reflect uncertainties associated with mass spectrometric measurements and the detrital $\mathrm{U} / \mathrm{Th}$ ratio.

\subsection{Grain size measurements}

Grain size measurements were made using an LS200 Coulter laser particle size analyzer at the University of Bremen. Biogenic sediments were removed prior to grain size analysis using a modification of the method of Mulitza et al. (2008) (Supplementary Material). The grain size distribution below $250 \mu \mathrm{m}$ was used for grain size endmember modeling. Reproducibility estimated from 13 replicates was 0.07 percentage points, or $5 \%$ of the average proportion in each bin. Seven outliers were removed from the dataset based on the criterion that their deviation from both adjacent samples averaged greater than 1 percentage point per bin.

\subsection{Grain size endmember modeling}

In order to separate eolian from hemipelagic inputs, we fit the grain size data for each core using Weibull distributions. These unimodal, asymmetric distributions closely approximate measured grain size distributions of airborne dust and loess (Zobeck et al., 1999; Sun, 2004). Following previous work on the northwest African margin (Holz et al., 2004, 2007; Mulitza et al., 2008; Tjallingii et al., 2008), we modeled grain size distributions using three endmembers per core. Each Weibull distribution $\left(W_{n}\right)$ has a probability density function given by the following equation:

$W_{n}=\frac{\kappa_{n}}{\lambda_{n}}\left(\frac{x}{\lambda_{n}}\right)^{\kappa_{n}-1} e^{-\left(x / \lambda_{n}\right)^{\kappa_{n}}}$

where $x$ is grain size, $\kappa$ is a shape parameter determining the breadth of the distribution, and $\lambda$ is a scale parameter determining the modal value of the distribution. In our best-fit endmembers $\kappa$ varied from 1.2 to 5 and $\lambda$ varied from 9 to 90 . The model for a given sample's grain size distribution was then given as:

Model $=c_{1} W_{1}+c_{2} W_{2}+c_{3} W_{3}$

where the loading coefficients $c_{1}, c_{2}, c_{3}>0$ and $c_{1}+c_{2}+c_{3}=1$. A MATLAB routine was developed to determine the Weibull distributions that provided the best fit for each core, by minimizing the root-mean-square (RMS) deviation between the modeled and measured distributions. Average RMS deviations for each core were $0.15-0.20$ percentage points, or $10-15 \%$ of the mean value of each bin. The flux of each endmember was calculated by 
multiplying the loading coefficients $c_{1}-c_{3}$ by the terrigenous flux for that sample (Supplementary Material).

Previous studies in the region have determined endmember compositions using the endmember modeling algorithm (EMMA) of Weltje (1997) (Holz et al., 2004; Tjallingii et al., 2008). Fig. 2 shows that our Weibull distributions for core GC68 are similar to those determined for the nearby core GeoB7920-2 using EMMA (Tjallingii et al., 2008). To explore differences between the two approaches, we applied EMMA to grain size data from GC37, GC49 and GC68. The major features of each record are reproduced (Fig. S6). The mean dust flux magnitudes are also quite similar using the two approaches in GC49 and GC68; in GC37, dust fluxes are 75\% higher using EMMA.
Unlike Weibull distributions, EMMA-derived endmembers sometimes have secondary modes that mimic the primary modes of other endmembers (Fig. 2; Fig. S7). As a result, relative changes in EMMA-derived loading coefficients are larger than those derived from Weibull distributions, and so relative dust flux changes are greater. Dust flux changes are also more variable between cores than using the Weibull approach. While the Weibull approach finds a consistent factor of 4-5 increase in dust fluxes from the AHP to the Late Holocene (Fig. 5), the EMMAderived dust flux changes are a factor of 5-15 (Fig. S8). This lack of consistency, combined with the multimodal distributions derived from EMMA, lead us to prefer the Weibull approach in these cores.
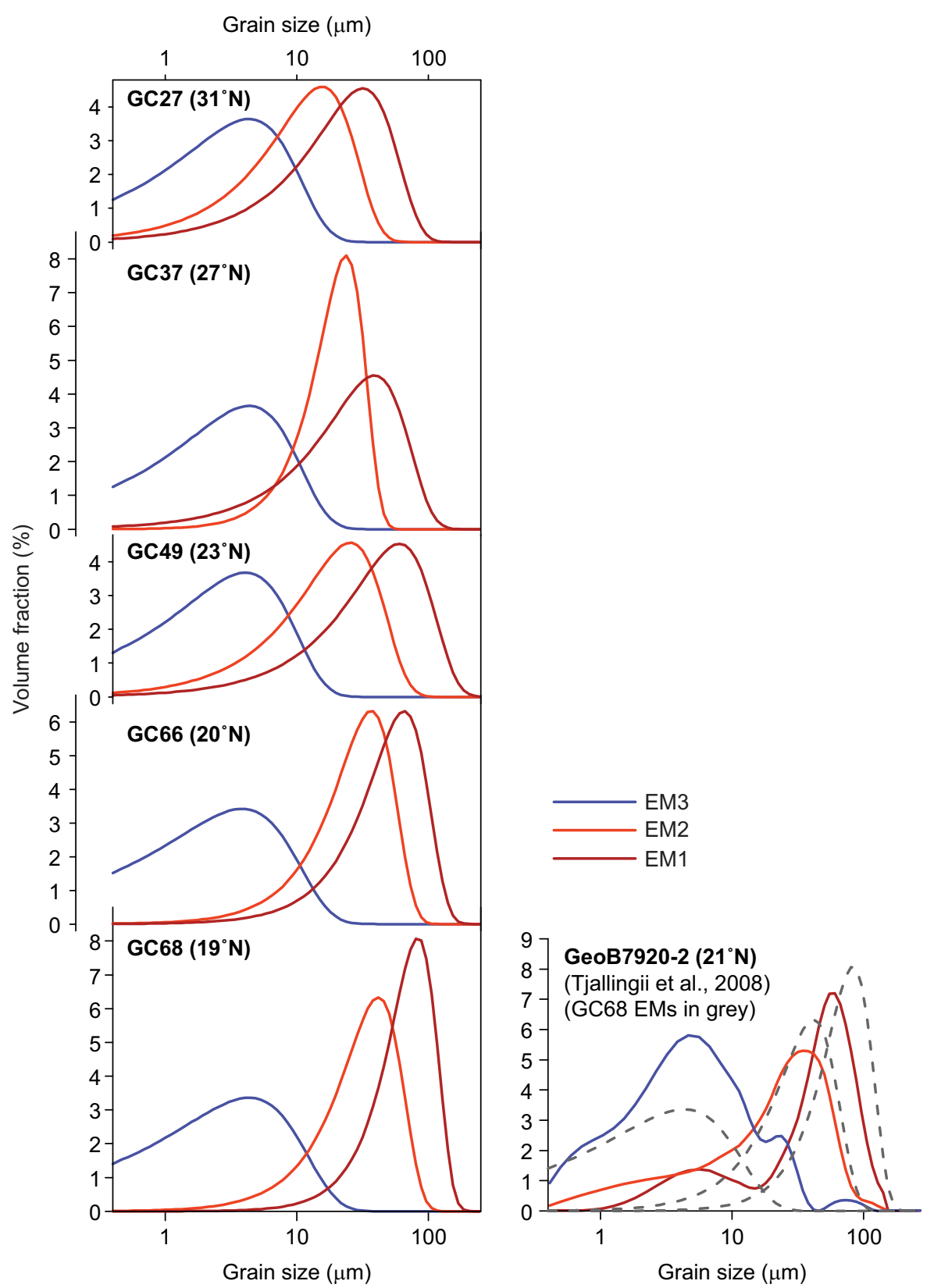

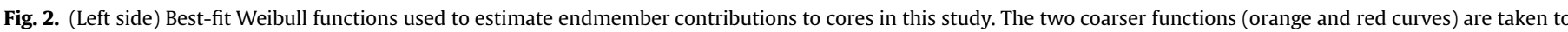

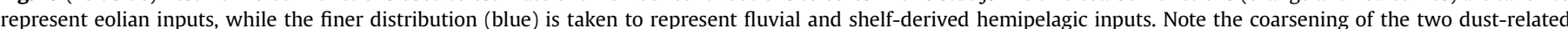

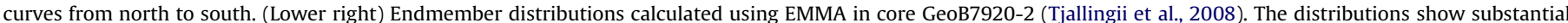

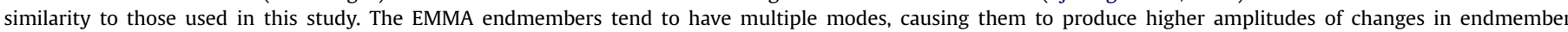

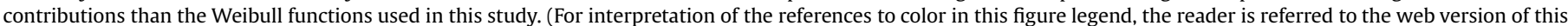
article.) 


\subsection{Endmember interpretations}

In studies of downcore samples and a spatial survey of surface sediments in this region, three endmembers describe $>85 \%$ of the variation in the grain size data (Holz et al., 2004; Tjallingii et al., 2008). Consistent with these studies, our finest endmember has a modal value of 4-6 $\mu \mathrm{m}$ and a broad distribution, while the coarser endmembers have narrower distributions and modes of $20-30 \mu \mathrm{m}$ and $>60 \mu \mathrm{m}$.

We identify the finest endmember (EM3) as reflecting inputs of fluvial suspended sediments and/or sediments resuspended from the continental shelf and transported downslope. Previous studies
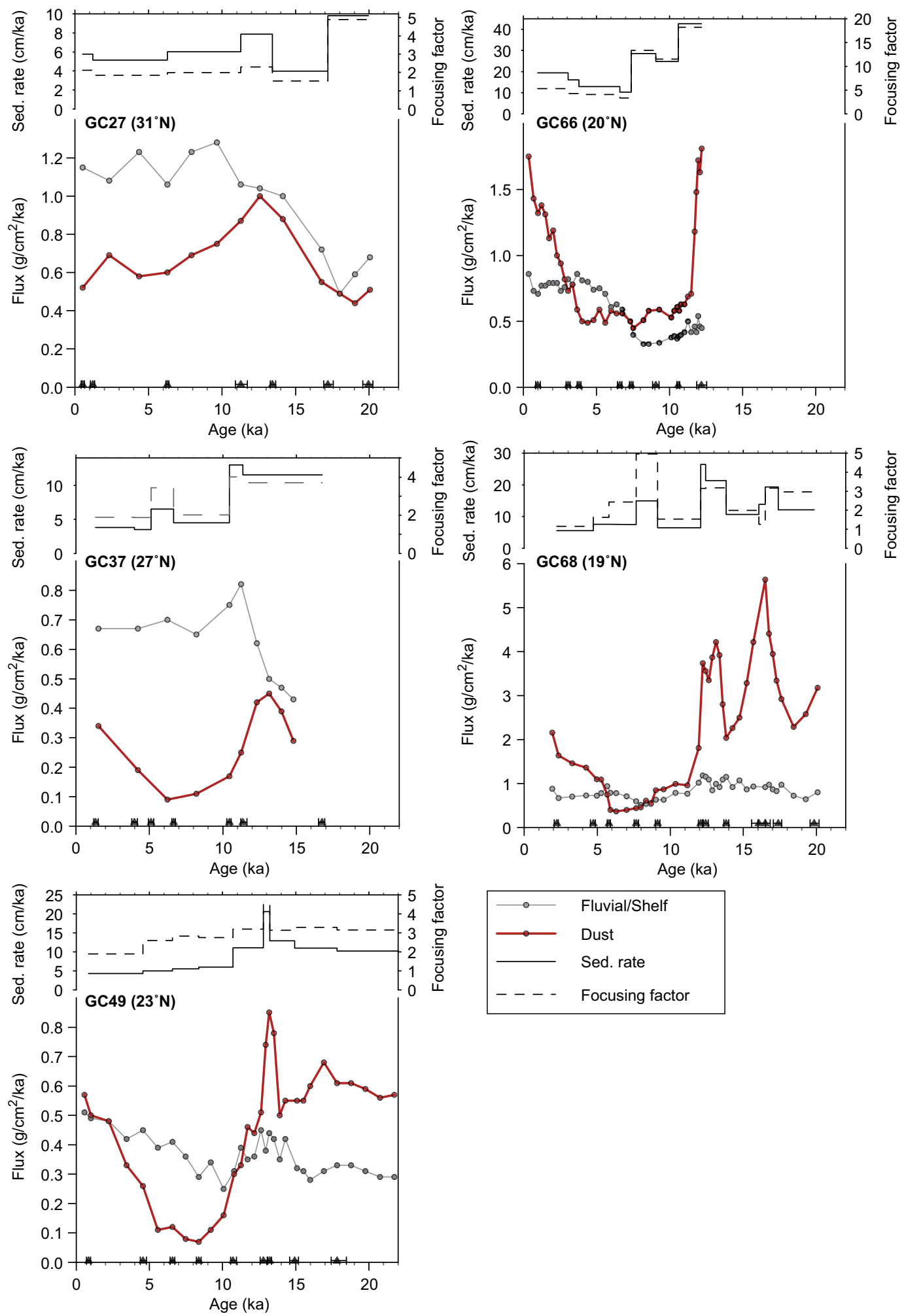

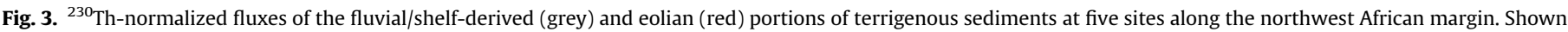

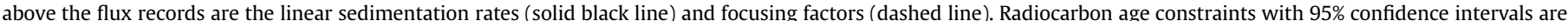

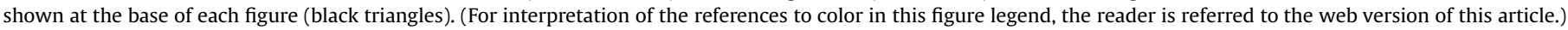


have linked EM3 to fluvial inputs (Tjallingii et al., 2008; Mulitza et al., 2008) based in part on the observation that fluvial suspended sediments in the region are almost exclusively $<10 \mu \mathrm{m}$ (Gac and Kane, 1986). Sediments resuspended from the shelf and transported downslope within nepheloid layers are similarly fine (McCave, 1983). Offshore transport of resuspended fine-grained continental shelf sediments is observed in the modern water column near our sites (Lam et al., 2012) and in similar continental margin settings (Anderson et al., 1994; Inthorn et al., 2006). The two coarser endmembers (EM1-2) are identified with eolian dust, based on observations that dust sampled near the coast has modal values between 8 and $25 \mu \mathrm{m}$ (Ratmeyer et al., 1999; Stuut et al., 2005), and that dust grains up to $90 \mu \mathrm{m}$ have been reported at Cape Verde (Glaccum and Prospero, 1980). Consistent with these inferred sources, grain size distributions similar to EM3 are found to be dominant in surface sediments near modern river mouths along the northwest African continental shelf, while distributions similar to EM1 and EM2 are found to be dominant under the core of the modern dust plume at $\sim 20^{\circ} \mathrm{N}$ (Holz et al., 2004). Additionally, elemental analyses of cores near the Senegal River indicate that the fine endmember is geochemically similar to fluvial suspended sediments (high $\mathrm{Fe} / \mathrm{K}$, high $\mathrm{Al} / \mathrm{Si}$ ), while the coarser endmembers are geochemically similar to eolian dust (Mulitza et al., 2008, 2010).

\section{Results}

\subsection{Eolian dust fluxes}

Eolian fluxes were calculated as the sum of the ${ }^{230} \mathrm{Th}$ normalized fluxes of the two coarser endmembers. Eolian fluxes show a systematic increase from north to south between $27^{\circ} \mathrm{N}$ and $19^{\circ} \mathrm{N}$ throughout the last $20 \mathrm{ka}$, with fluxes at GC68 $\left(19^{\circ} \mathrm{N}\right)$ approximately a factor of 4-6 higher than fluxes at GC37 $\left(27^{\circ} \mathrm{N}\right)$ (Figs. 3 and 4). The flux records are variably affected by smoothing by bioturbation. Fluxes in the high-LSR cores GC68 and, to a lesser extent, GC49 show centennial- to millennial-scale features, while the record from GC37 shows only multi-millennial averages of dust fluxes.

In summarizing our dust flux records we focus on cores GC37, GC49 and GC68. These cores have relatively consistent focusing factors (average 2.7-3.1) and are not known to be located near submarine canyon systems. GC66 is located near the Cap Timiris canyon system and shows extremely high and variable sediment focusing; focusing factors range from 11 to 18 prior to $7.4 \mathrm{ka}$, then fall to 3.3-5.3 (Fig. 3). The magnitude and variability of lateral advection at this site suggest that its record of dust fluxes should be interpreted with caution. GC27 does not have high focusing factors, but its location near the large Agadir canyon system suggests that its dust flux record should be replicated before being considered representative of dust fluxes near $31^{\circ} \mathrm{N}$.

In GC68 and GC49, dust fluxes at $20 \mathrm{ka}$ are approximately equal to fluxes over the last $2 \mathrm{ka}$. Fluxes then rise in Heinrich Stadial 1 (HS1; 18-15 ka). The HS1 peak in GC68 is especially prominent, a factor of $\sim 2.5$ higher than the 0-2 ka average and a factor of 14 above the late AHP (8-6 ka) average (Figs. 4 and 5). The record from GC49 shows only a muted rise during HS1, possibly due to its lower LSR during this period. Both GC49 and GC68 show a drop in dust flux at 15-14 ka to levels near those of the last $2 \mathrm{ka}$, followed by a sharp peak in dust fluxes, reaching $50-90 \%$ higher than $0-2 \mathrm{ka}$ levels. This peak occurs between $13.5-12.9 \mathrm{ka}$ in GC49 and 13.3-12.2 ka in GC68. Similarly, dust fluxes in GC37 rise at $\sim 12 \mathrm{ka}$ to values $30 \%$ higher than mean fluxes during the last $2 \mathrm{ka}$. These dust flux changes are approximately correlative with the Bølling-Allerød warm period (14.7-12.9 ka) and Younger
Dryas (YD) cold period (12.9-11.7 ka), respectively (ages from Rasmussen et al. (2006)).

Dust fluxes fall sharply at the end of the YD, marking the start of the AHP. In GC49 and GC68, the two cores that appear to record the full amplitude of the change, dust fluxes fall by a factor of 8.5 and 7.1, respectively, from the Younger Dryas peak to the mean for 6-10 ka. During the AHP, dust fluxes are at their lowest levels in the four cores between $19^{\circ} \mathrm{N}$ and $27^{\circ} \mathrm{N}$. Fluxes in GC49 are low and relatively constant, while fluxes in GC68 are higher in the beginning of the AHP and lower between 8 and $6 \mathrm{ka}$, similar to the record from ODP Site 658C. The lower-resolution dust flux record from GC37 also shows minimum dust fluxes during the AHP. Dust fluxes averaged over 6-8 ka in each core rise steadily from north to south along the transect, from $0.092 \mathrm{~g} / \mathrm{cm}^{2} / \mathrm{ka}$ at GC37 to 0.41 $\mathrm{g} / \mathrm{cm}^{2} / \mathrm{ka}$ at GC68.

Dust fluxes begin rising at GC37, GC49 and GC68 just after 6 ka. At GC68, dust fluxes rise by a factor of 2.7 between $5.9 \mathrm{ka}$ and $5.3 \mathrm{ka}$, while at GC49 dust fluxes rise by a factor of 2.4 between $5.6 \mathrm{ka}$ and $4.6 \mathrm{ka}$. GC37 shows only a smooth rise in dust fluxes from $6 \mathrm{ka}$ to the coretop due to its low LSR in this interval. GC66 is anomalous, with a dust flux rise that does not begin until after $4 \mathrm{ka}$ and proceeds gradually. All four cores between $27^{\circ} \mathrm{N}$ and $19^{\circ} \mathrm{N}$ indicate gradually rising dust fluxes over the last $4 \mathrm{ka}$, reaching values over the last $2 \mathrm{ka}$ that are approximately a factor of 5 higher than mean values from 6 to 8 ka (Fig. 5).

Dust fluxes at GC27 $\left(31^{\circ} \mathrm{N}\right)$ do not appear similar to the records from the four southern cores. Dust fluxes show little variability, changing by only a factor of 0.5 relative to the mean, and are substantially higher than at GC37 $\left(27^{\circ} \mathrm{N}\right)$.

\subsection{Fluvial/shelf-derived sediment fluxes}

Fluxes of the fine endmember (EM3), believed to reflect inputs of fluvial and resuspended shelf sediments, range between 0.25 and $2.0 \mathrm{~g} / \mathrm{cm}^{2} / \mathrm{ka}$ in the five cores (Fig. 3). EM3 fluxes do not show consistent changes between cores or systematic north-south trends, and changes are of lower amplitude than changes in eolian fluxes. EM3 fluxes are lowest at GC49, the deepest core in the transect, approximately equal at GC37, GC66 and GC68, and highest at GC27.

\subsection{Carbonate percentages}

Fig. 6 shows carbonate percentage data for 10 cores between $19^{\circ} \mathrm{N}$ and $31^{\circ} \mathrm{N}$. The eight cores south of $28^{\circ} \mathrm{N}$ show a consistent pattern of high carbonate percentages between $\sim 12$ and $5 \mathrm{ka}$ and lower carbonate percentages after $5 \mathrm{ka}$. Several cores also show carbonate minima at $12-13 \mathrm{ka}$. Based on ${ }^{230} \mathrm{Th}$-normalized flux data from ODP Site 658C (Adkins et al., 2006) and the cores in this study, carbonate percentages in cores in this region primarily reflect variable dilution by dust. The carbonate data thus suggest that the pattern of increased dust fluxes during the Younger Dryas and Late Holocene and reduced dust fluxes during the AHP observed in cores with flux data occurs across a broad area between $19^{\circ} \mathrm{N}$ and $27^{\circ} \mathrm{N}$.

\section{Discussion}

\subsection{Consistency checks for endmember fluxes and grain size distributions}

Satellite and sediment trap data provide a means of assessing whether our coretop dust flux estimates are reasonable. Satellite data indicate a monotonic increase in atmospheric dust loads from north to south along our transect, with peak AOD just south of our 


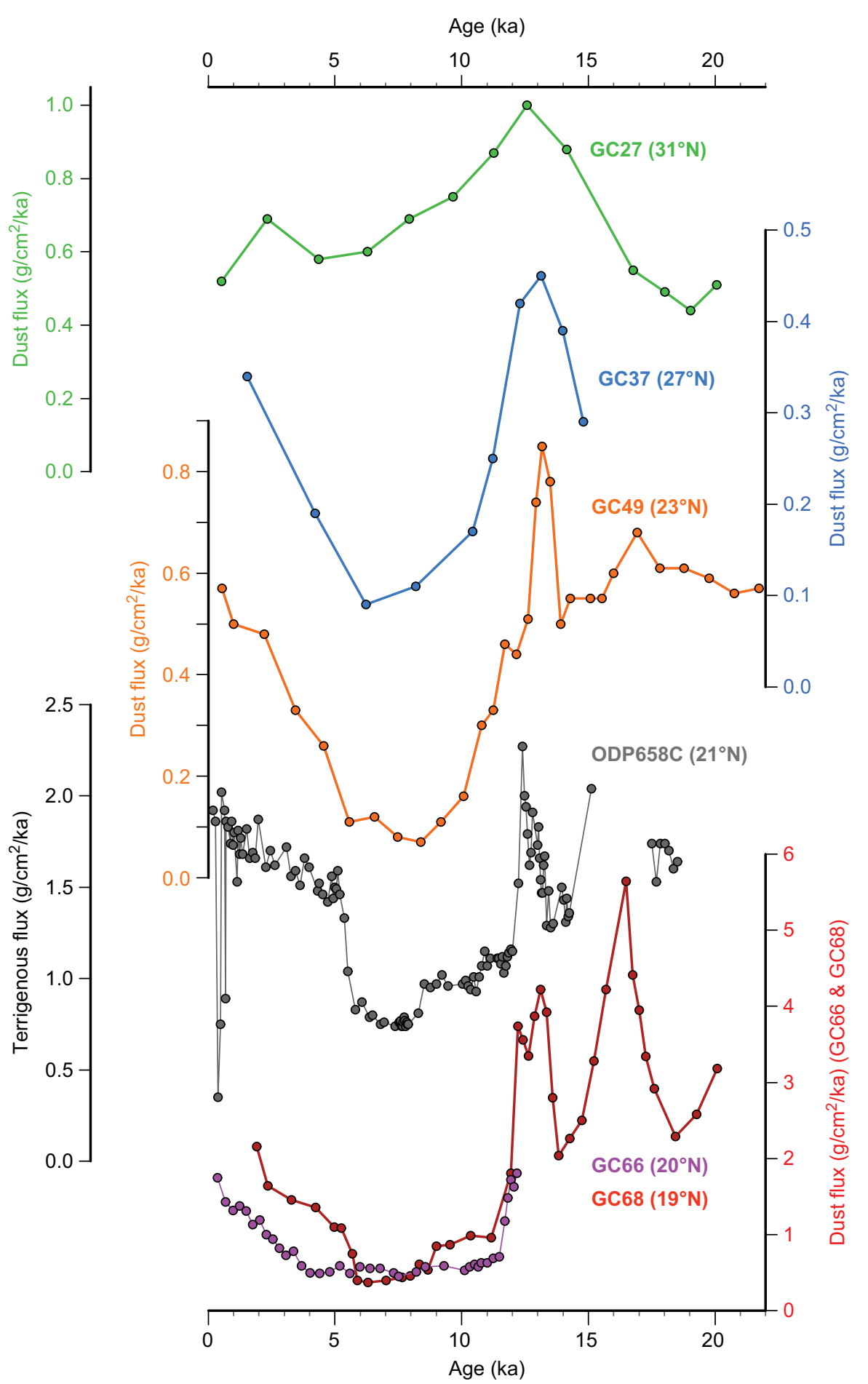

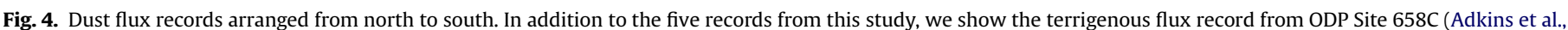
2006). The records from cores GC66 and GC27 are suspected of being compromised by their proximity to major submarine canyon systems.

southernmost core (Fig. 1). Sediment traps between 700 and $1140 \mathrm{~m}$ water depth along the margin record a factor of $\sim 4$ increase in lithogenic fluxes from $29.1^{\circ} \mathrm{N}$ to $18.3^{\circ} \mathrm{N}$ (Ratmeyer et al., 1999; Bory and Newton, 2000).

Our average $0-2$ ka dust fluxes between $27^{\circ} \mathrm{N}$ and $19^{\circ} \mathrm{N}$ appear consistent with these data, showing a monotonic increase of a factor of $\sim 6$ from GC37 to GC68. Our dust flux estimates are also quite close in magnitude to those from sediment traps: in sediment trap studies, fluxes rise from $4.2 \mathrm{~g} / \mathrm{m}^{2} / \mathrm{yr}$ at $29^{\circ} \mathrm{N}$ to $18 \mathrm{~g} / \mathrm{m}^{2} / \mathrm{yr}$ at $18^{\circ} \mathrm{N}$, while our $0-2$ ka dust flux averages are $3.4 \mathrm{~g} / \mathrm{m}^{2} / \mathrm{yr}$ at $27^{\circ} \mathrm{N}$ and
$22 \mathrm{~g} / \mathrm{m}^{2} / \mathrm{yr}$ at $19^{\circ} \mathrm{N}$. Given the degree of decadal-scale variability in African dust fluxes (Prospero and Lamb, 2003) and the different timescales of the measurements (1-3 yr for sediment traps, last $2 \mathrm{ka}$ for sediments), this high level of agreement may be somewhat fortuitous, but it lends a basic level of confidence to the magnitude of our reconstructed fluxes. Dust fluxes at GC27 $\left(31^{\circ} \mathrm{N}\right)$ are an exception, as they are higher than at GC37 to the south. GC27 also shows a different dust flux history than the southern cores (Fig. 4). Lacking other cores at this latitude, we do not know whether these fluxes accurately reflect local dust deposition or whether this core's 
record is compromised, perhaps due to its location near the Agadir submarine canyon.

In contrast to dust fluxes, fine endmember fluxes show no clear meridional or temporal patterns (Fig. 3). Our results do not support a strong link between fine endmember fluxes and either sea level or climate at these sites. Direct inputs of suspended fluvial sediments would be expected to increase with increasing river discharge during the AHP, suggesting that fine endmember fluxes at these sites may primarily reflect resuspension and offshore transport of fine-grained continental shelf sediments.

Endmember Weibull distributions for our cores show minimal differences in the fine endmember, but the modal grain sizes of the two dust-related endmembers increase from north to south (Fig. 2). This finding is consistent with surface wind data from the NCEP reanalysis (Kalnay et al., 1996), which indicate that winter surface winds increase toward the south along our transect.

\subsection{Dust fluxes over the last $20,000 \mathrm{yr}$}

\subsubsection{The LGM and Heinrich Stadial 1}

Our dust flux records from GC37, GC49 and GC68 replicate the major features of the ODP Site 658C record while providing new information about dust fluxes during Heinrich Stadial 1 (HS1). During the LGM portion of the records (20-18 ka), dust fluxes are only slightly higher than in the last $2 \mathrm{ka}$. During HS1, dust fluxes rise to their maximum levels in GC68, our highest-resolution core. Previous work has suggested that dust emissions during HS1 reached their highest point in the last $50 \mathrm{ka}$ (Jullien et al., 2007; Tjallingii et al., 2008; Mulitza et al., 2008), but the record from GC68 provides the first quantitative estimate of North African dust fluxes during this period, suggesting that dust fluxes were a factor of $\sim 2.6$ higher than mean $0-2$ ka fluxes. This represents a minimum estimate, as bioturbation may have reduced the HS1 peak height. At GC49, the HS1 peak is evident only as a much smaller rise. The amplitude of the peak may have been reduced by bioturbation, as this is a period of somewhat low LSRs at GC49;

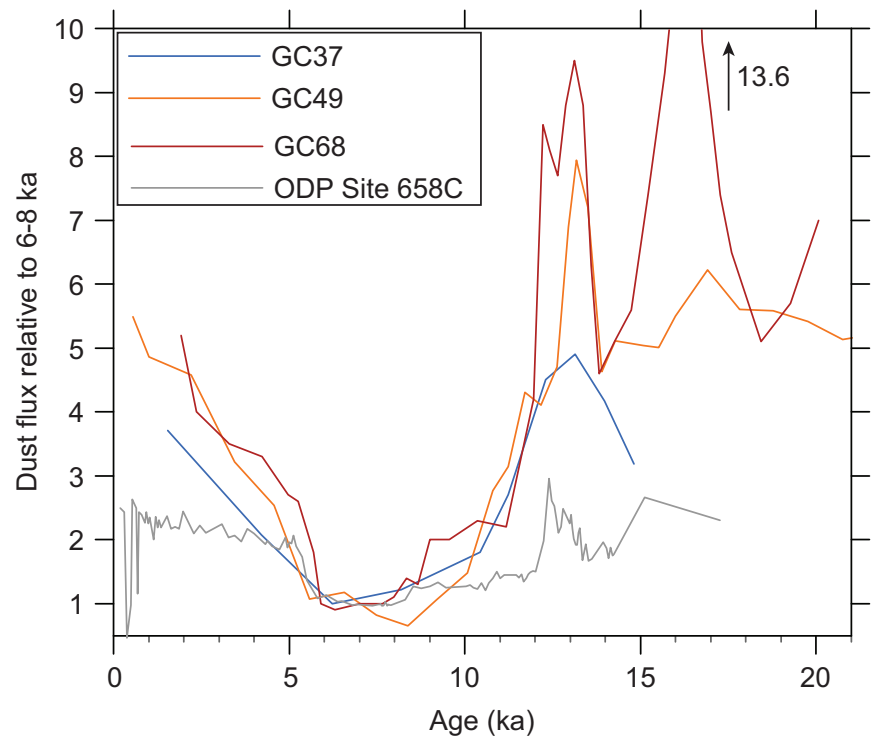

Fig. 5. Dust fluxes for GC37, GC49, GC68 computed relative to their average 6-8 ka values compared to similarly normalized terrigenous flux values from ODP Site $658 \mathrm{C}$. The three cores from this study show a higher amplitude of change due to the use of endmember modeling to estimate hemipelagic inputs, which comprise a substantial portion of total terrigenous fluxes during the AHP. Results from this study suggest that AHP dust fluxes were a factor of $\sim 5$ lower than fluxes over the last $2 \mathrm{ka}$. alternatively, high HS1 dust emissions could have been limited to areas south of $23^{\circ} \mathrm{N}$

\subsubsection{The Younger Dryas}

Dust fluxes in GC37, GC49 and GC68 are low between 15 and $13.5 \mathrm{ka}$, a period approximately correlative with the BøllingAllerød warm period and with lake expansions in North Africa (Gasse, 2000). Dust fluxes rise in all three cores during a period approximately correlative with the Younger Dryas; however, when compared to the age of the YD in Greenland ice (11.7-12.9 ka; Rasmussen et al., 2006), these peaks generally appear to be offset toward older ages in GC68 and GC49. The peaks also display variable degrees of abruptness, with GC37 showing especially gradual changes.

We used a simple bioturbation model to investigate the effects of bioturbation on the timing and abruptness of end-YD dust

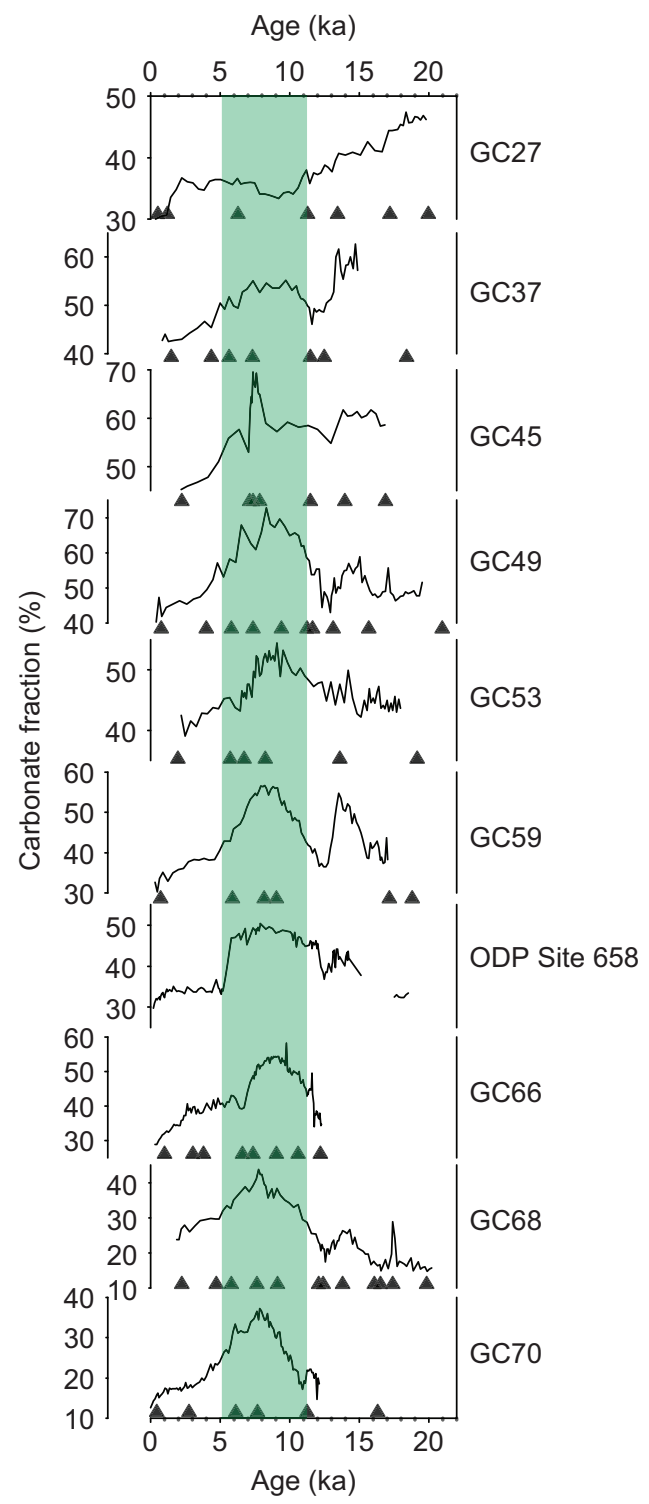

Fig. 6. Carbonate percent data for 10 cores between $19^{\circ} \mathrm{N}$ and $27^{\circ} \mathrm{N}$ along the northwest African margin. Triangles indicate ${ }^{14} \mathrm{C}$ ages used for age-depth models for the eight cores from this study. Cores show high carbonate percentages during the AHP (11.7-5 ka; indicated by green shading) and low carbonate percentages during the YD (12.9-11.7 ka) and Late Holocene (5-0 ka), reflecting low and high dust fluxes, respectively. Data from ODP Site 658C are from deMenocal et al. (2000). (For interpretation of the references to color in this figure legend, the reader is referred to the web version of this article.) 
changes in cores GC37, GC49, GC68 and ODP Site 658C. We assumed a mixed layer of $5 \mathrm{~cm}$ that is completely homogenized (e.g., Berger and Heath, 1968) and used the observed end-YD sedimentation rates for each core. We then constructed synthetic input signals for end-YD dust changes and deposited them in the model sediment column at time steps of $50 \mathrm{yr}$. We compared the results to dust concentration data for each core, as these data are available at a higher resolution than dust fluxes.

Fig. 7B shows the input signals that produced the best fit to the data after being run through the bioturbation model. For all cores, a

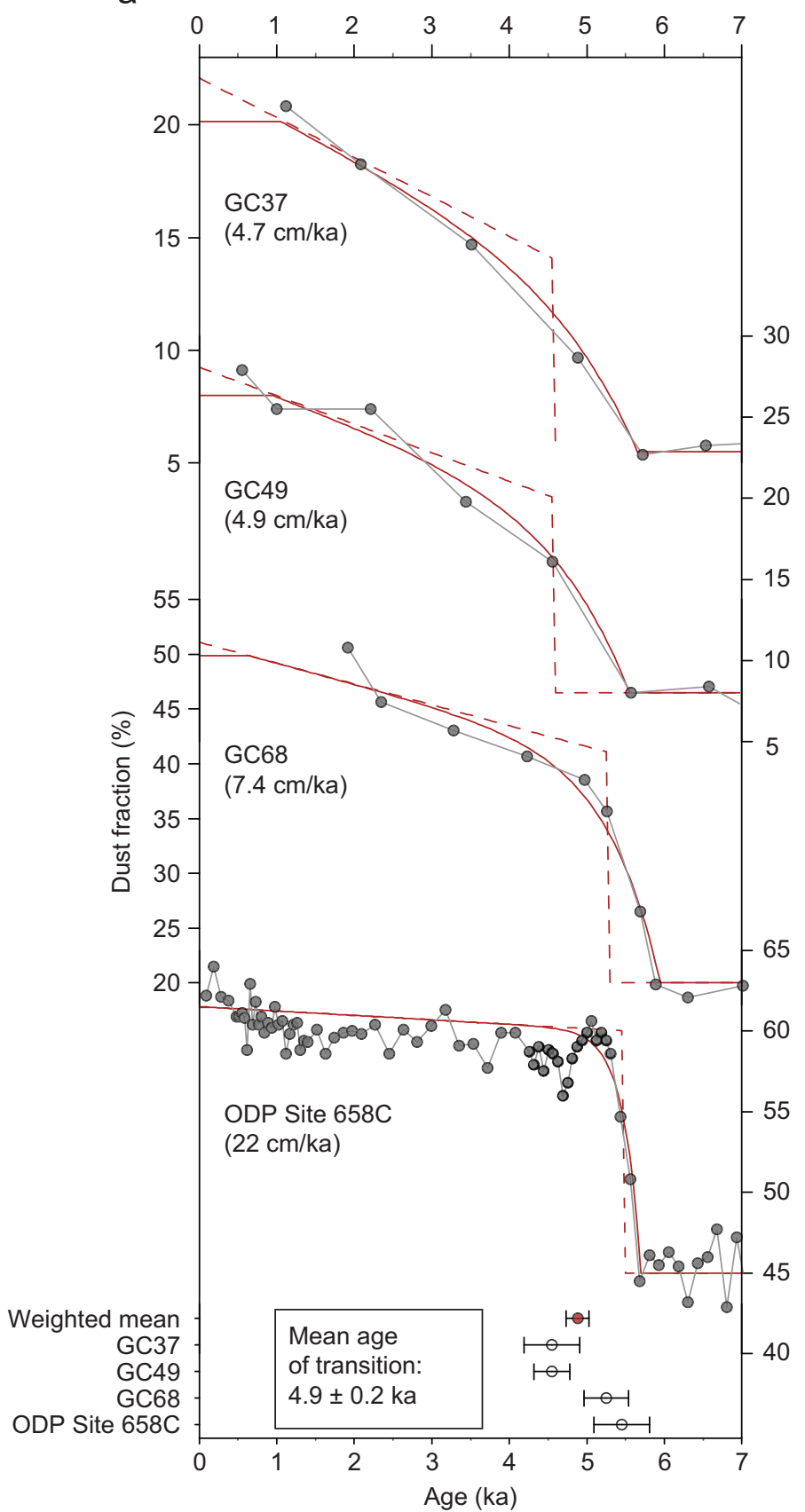

b

b

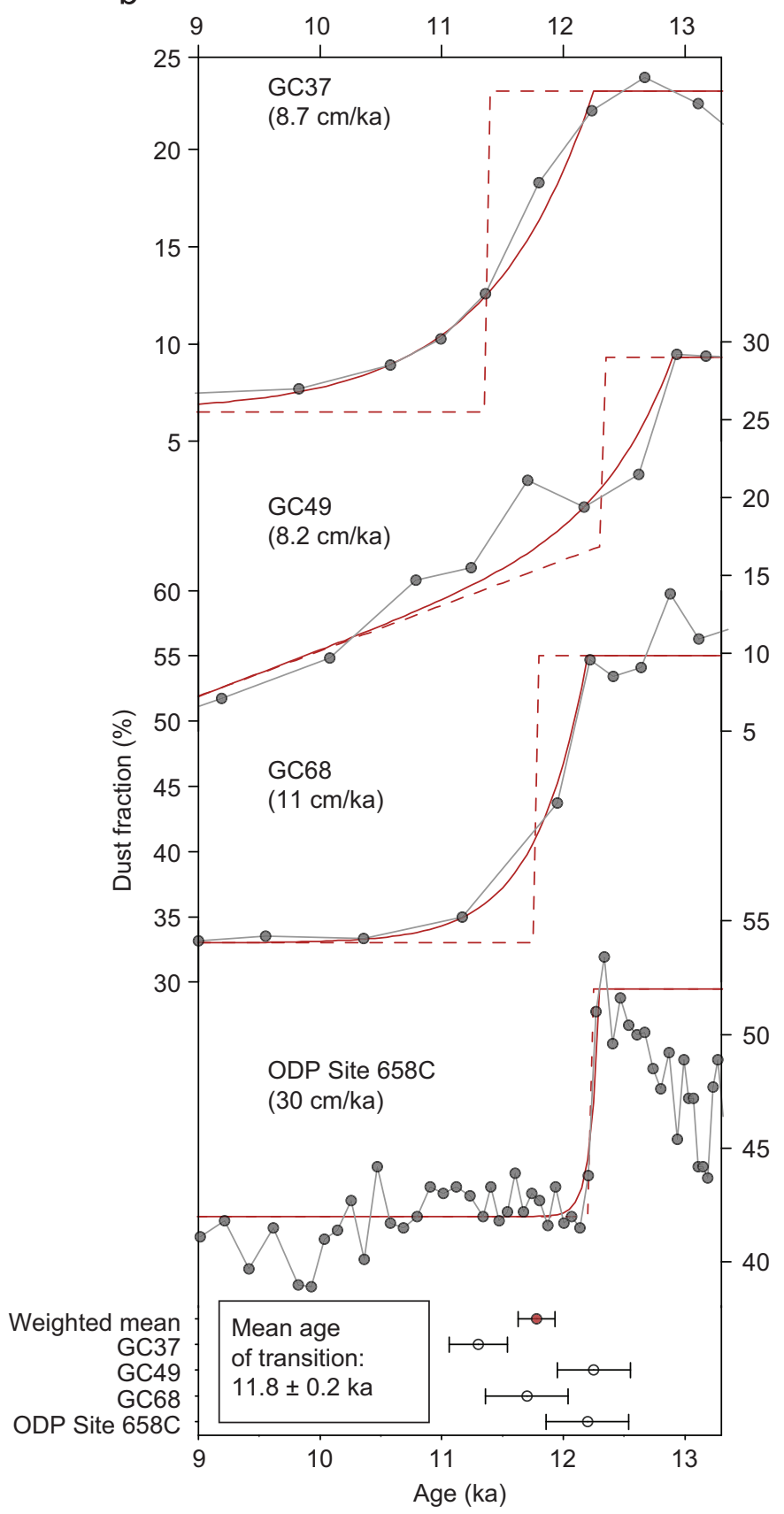

$$
\begin{gathered}
----- \text { Input signal } \\
\text { B Bioturbated signal } \\
\text { D Data }
\end{gathered}
$$

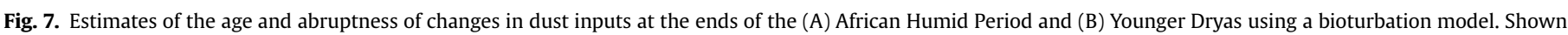

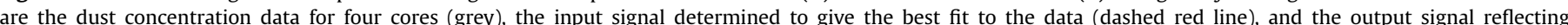

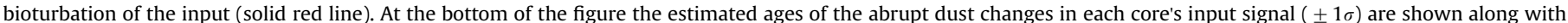

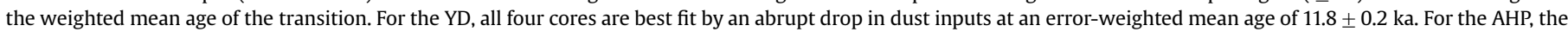

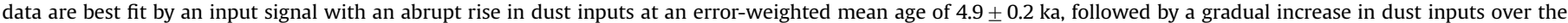
remainder of the Late Holocene. (For interpretation of the references to color in this figure legend, the reader is referred to the web version of this article.) 
the data are best fit by an input signal with an abrupt drop in dust concentration sometime between 12.3 and $11.4 \mathrm{ka}$. For each core, we estimate the age uncertainty of the abrupt change in the input signal using the uncertainty of the age model and an additional uncertainty of $400 \mathrm{yr}$ reflecting uncertainty in the sedimentation rate and bioturbation depth. Taking the ages of the drops in the input signals for the four cores as independent estimates of the age of the end-YD drop in dust emissions, we obtain an error-weighted mean age of $11.8 \pm 0.2 \mathrm{ka}(1 \sigma)$, in agreement with the established end-YD age (11.7 $\pm 0.1 \mathrm{ka}$; Rasmussen et al., 2006). This agreement suggests that the $\sim 12$ ka dust flux peaks in each core are correctly associated with the YD, and that the apparent age offsets between the peaks and the YD reflect a combination of random age model errors and systematic offsets toward older ages due to bioturbation.

\subsubsection{The African Humid Period and Late Holocene}

Dust fluxes are low between the end of the YD and $\sim 5 \mathrm{ka}$ in GC37, GC49 and GC68, corroborating low AHP dust fluxes observed at ODP Site 658C. Average fluxes between 10 and 6 ka rise by a factor of 4.5 from $27^{\circ} \mathrm{N}$ to $19^{\circ} \mathrm{N}$. This value is similar to the $0-2 \mathrm{ka}$ dust flux gradient and does not suggest a large change in the orientation of the dust plume during the AHP. From north to south, 10-6 ka dust fluxes are factor of 4.4, 8.5 and 7.1 lower than peak YD fluxes; the lower amplitude of change at GC37 is likely to reflect bioturbative mixing due to low LSRs (Fig. 3). These YD-AHP dust flux changes are substantially larger than observed at ODP Site 658C (factor of 3.6; Fig. 5) (Adkins et al., 2006), a record that does not separate eolian and fluvial/shelf inputs. Fluvial/shelf inputs are generally minor in times of high dust flux but comprise a substantial portion of the sediment during the AHP (Tjallingii et al., 2008), potentially resulting in a reduced amplitude of change into and out of the AHP at ODP Site 658C.

At the end of the AHP, dust fluxes quickly rise by a factor of $\sim 2$ at GC68 and GC49, then rise more gradually toward the coretop. In both cores, the difference between end-AHP (8-6 ka) and 0-2 ka dust fluxes is a factor of 5.2. Again, this change is substantially greater than at ODP Site $658 \mathrm{C}(2.1)$, which we attribute to the damping effects of fluvial/shelf inputs. We note that use of the endmember modeling approach taken by previous studies in the region (Tjallingii et al., 2008; Mulitza et al., 2008) rather than Weibull distributions would only increase the amplitude of dust flux changes from the YD to the AHP to the Late Holocene (Section 4.4; Fig. S6).

To evaluate the timing and abruptness of the dust flux rise at the end of the AHP, we applied the same bioturbation model used to investigate the end-YD change (Section 6.2.2). We find that the dust concentration changes after $6 \mathrm{ka}$ are best explained by an abrupt increase in dust in each core sometime between 5.5 and $4.6 \mathrm{ka}$, followed by a gradual rise in dust inputs over the remainder of the Late Holocene (Fig. 7A). This gradual rise is consistent with the dust flux record from ODP Site 658C after $5 \mathrm{ka}$. In cores GC37, GC49 and GC68, the abrupt rise accounts for $~ 50 \%$ of the observed AHP-to-coretop increase in dust concentration.

Our data do not exclude an asynchronous end of the AHP, as cores GC37 and GC49 indicate younger ages for the transition than do GC68 and ODP Site 658C (Fig. 7A). However, the spread in ages is the same as the spread in ages associated with the end-YD transition (Fig. 7B). As it seems reasonable to assume that the abrupt end-YD transition, driven by high-latitude changes, was in fact synchronous, these offsets may reflect random age model errors rather than true asynchrony. The fact that the age of the end-YD drop estimated by our bioturbation model agrees well with the end-YD age in Greenland suggests that this model provides a reasonable and robust method for estimating the true age of the end-AHP dust flux rise. Taking the age estimates from the four cores, the weighted mean age of the abrupt end-AHP rise in dust is $4.9 \pm 0.2 \mathrm{ka}, \sim 600 \mathrm{yr}$ younger than the estimate based on ODP Site 658C alone.

\subsection{Regional context and drivers of North African dust emissions over the last $20 \mathrm{ka}$}

The close agreement of dust flux records between 19 and $27^{\circ} \mathrm{N}$ (Figs. 4 and 5), as well as the agreement of carbonate percentage records from a larger suite of cores (Fig. 6), indicate that the dust flux changes recorded at highest resolution in ODP Site 658C and GC68 are representative of a broad region of northwest Africa over the last $20 \mathrm{ka}$.

The record from GC68, which offers the highest-resolution continuous African dust flux record of the last $20 \mathrm{ka}$, demonstrates a close relationship between North African dust emissions and Atlantic SST gradients (Fig. 8) (Shakun et al., 2012). Colder SSTs in the North Atlantic are closely matched by higher dust fluxes in GC68 during HS1 and the YD, and warmer North Atlantic SSTs are associated with lower dust fluxes during the Early Holocene AHP. This SST-dust relationship is similar to that observed over the last 30-50 yr (e.g., Wong et al., 2008; Evan et al., 2011) as well as on millennial, orbital and Plio-Pleistocene timescales (deMenocal et al., 1993; deMenocal, 1995; Tjallingii et al., 2008; Mulitza et al., 2008).

Our dust flux data also display significant correlations with opal fluxes at the three cores at which both have been measured (Fig. 9) (Bradtmiller, L., unpublished data). A similar correlation has been observed at ODP Site 658C (Adkins et al., 2006). Opal fluxes in this region are interpreted to reflect in part the strength of coastal trade winds driving upwelling (Adkins et al., 2006; Romero et al., 2008). This correlation suggests an important role for surface winds in the observed dust changes, either as a dominant control or in conjunction with precipitation and vegetation changes. The importance of wind speed - and in particular changes in wind gustiness linked to meridional temperature gradients - in driving dust emissions has been highlighted by studies of both the modern world (Engelstaedter and Washington, 2007a,b; Doherty et al., 2012) and paleoclimates (McGee et al., 2010; Roskin et al., 2011). Studies of dune activity in low latitude settings indicate a primary role for gustiness in preventing dune stabilization by vegetation (Tsoar, 2005; Chase, 2009; Yizhaq et al., 2009), and studies in coastal northwest Africa indicate three periods of dune activity over the last 25 ka approximately correlative with the HS1, YD and Late Holocene dust maxima observed in offshore cores (Swezey, 2001; Lancaster et al., 2002).

The dust flux rise from the LGM to HS1 in GC68 appears most plausibly linked to wind speed changes. Pollen data indicate that the Saharan dust source areas for our sites were likely dry and unvegetated during both periods (Dupont, 1993), suggesting that aridity was not the driver of changing dust emissions. A primary role for winds in driving HS1 dust fluxes is supported by increased biogenic sediment accumulation rates during HS1 (Romero et al., 2008; Zarriess and Mackensen, 2010), consistent with increased coastal upwelling driven by stronger winter trade winds. Stronger surface winds along the NW African margin are a consistent response in 'hosing' experiments modeling conditions analogous to Heinrich events; they appear related to the strengthened winter Hadley circulation in the Northern Hemisphere that accompanies a cooling in the North Atlantic relative to the South Atlantic (Vellinga and Wood, 2002; Broccoli et al., 2006; Chiang and Friedman, 2012).

Our records support an abrupt, large-magnitude drop in dust emissions at the end of the YD, consistent with abrupt changes in Greenland temperatures, North Atlantic SSTs and global monsoon 


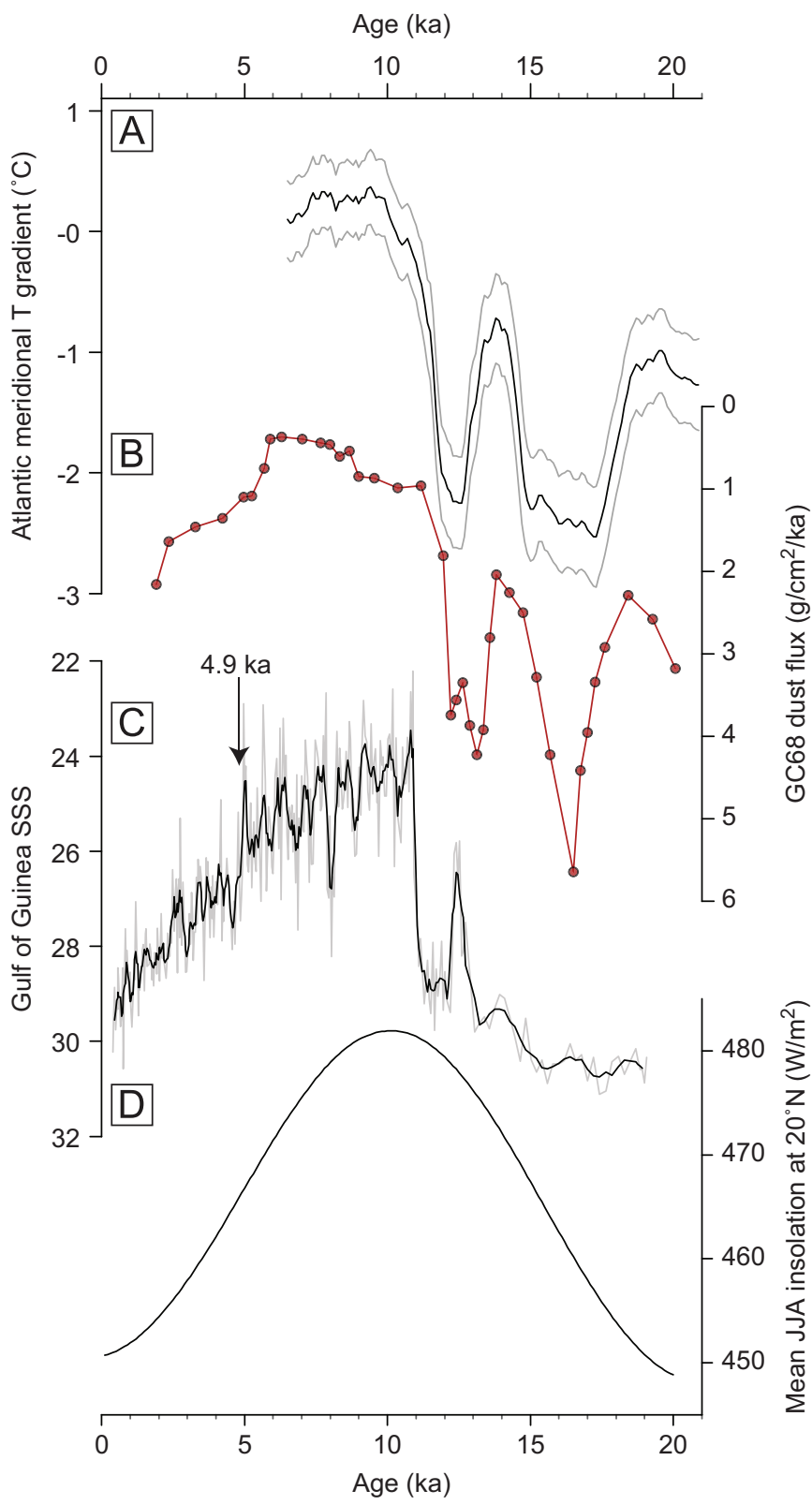

Fig. 8. Records of regional climate and insolation over the last $20 \mathrm{ka}$. (A) Atlantic Ocean interhemispheric SST gradient estimates (Shakun et al., 2012). Values are expressed relative to the 6 ka gradient, with negative values indicating cooler SSTs north of the equator. (B) Dust fluxes in core GC68 shown on a reversed scale. (C) Sea-surface salinity (SSS) estimated from $\mathrm{Ba} / \mathrm{Ca}$ ratios of the planktonic foraminifer Globigerina ruber from core MD03-2707 in the Gulf of Guinea, taken as an indicator of relative changes in the outflow of the Niger and Sanaga rivers, with higher outflow oriented up on the graph (Weldeab et al., 2007). An abrupt decrease in river outflow (increase in SSS) is indicated at $4.9 \mathrm{ka}$, at the same time as our best estimate of the end-AHP dust flux rise. The black line is a 5-point moving average of the raw data (grey). (D) Mean JJA insolation at $20^{\circ} \mathrm{N}$ (Laskar et al., 2004).

systems at this time. This dramatic decline in dust flux (a factor of 8) likely reflects a combination of decreased wind gustiness and increased precipitation associated with a northward shift of the ITCZ at this time. Proxy data suggest decreased upwelling intensity in the AHP, consistent with weakened surface winds (Adkins et al., 2006; Zarriess and Mackensen, 2010), while lake level and pollen records suggest higher precipitation (Hoelzmann et al., 1998; Gasse, 2000).

Significantly, our records appear to require an abrupt increase in dust emissions at the end of the AHP, a time not marked by

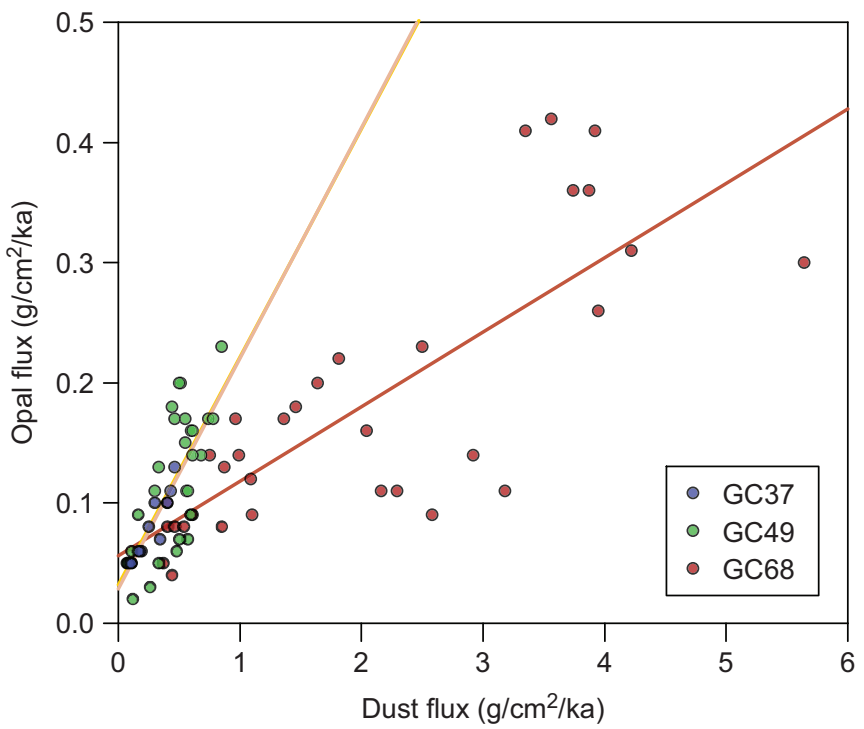

Fig. 9. Correlations between ${ }^{230} \mathrm{Th}$-normalized dust and opal fluxes in the three cores from this study in which both were measured. Best-fit lines are shown for GC68 data (red) and GC37 and GC49 data (orange; lines for the two cores overlie each other). $r^{2}$ values are as follows: 0.85 (GC37), 0.50 (GC49), 0.61 (GC68). Opal flux data are from L. Bradtmiller, (unpublished data). (For interpretation of the references to color in this figure legend, the reader is referred to the web version of this article.)

abrupt changes in external forcings. This study thus corroborates the abrupt dust flux rise at the end of the AHP at ODP Site 658C (deMenocal et al., 2000), which has been the focus of modeling efforts to understand abrupt changes in North African climate in response to gradual climate forcing (Brovkin et al., 2002; Renssen et al., 2003; Wang et al., 2005; Liu et al., 2006, 2007). Our data suggest two modifications of our understanding of this abrupt change: (1) the use of grain size endmember modeling suggests that dust fluxes prior to the end of the AHP were lower than indicated by ODP Site $658 \mathrm{C}$ and that the amplitude of the abrupt end-AHP increase in dust emissions was thus higher (factor of 2.53 vs. factor of $<2$ ); and (2) combining records from four sites and using a bioturbation model, we provide a revised estimate for the age of the end of the AHP of $4.9 \pm 0.2 \mathrm{ka}$. This revised timing will inform comparisons of Holocene dust records with other highresolution records of African climate (e.g., Shanahan et al., 2006; Weldeab et al., 2007; Kröpelin et al., 2008; Tierney et al., 2008; Lézine 2009; Foerster et al., 2012). Importantly, our revised age agrees with an abrupt decrease in outflow from tropical West African rivers at $4.9 \mathrm{ka}$ reconstructed from $\mathrm{Ba} / \mathrm{Ca}$ ratios of planktonic foraminifera in a Gulf of Guinea core, which primarily reflect changes in sea surface salinity near the mouths of the Niger and Sanaga rivers (Fig. 8C) (Weldeab et al., 2007). It appears that rising dust emissions at the end of the AHP may have been accompanied by a similarly rapid reduction in West African monsoon precipitation in the Niger and Sanaga watersheds, inconsistent with the hypothesis that the abrupt end-AHP dust flux change was a nonlinear response to gradually decreasing mean precipitation (Liu et al., 2006, 2007).

\section{Conclusions}

Dust flux and carbonate percentage records from a suite of cores along the northwest African margin between 19 and $27^{\circ} \mathrm{N}$ show coherent patterns over the last $20 \mathrm{ka}$. By pairing ${ }^{230} \mathrm{Th}-$ normalized fluxes with grain size endmember modeling to estimate eolian fluxes, we corroborate the major features of the ODP 
Site 658C terrigenous flux record while also finding that this record may underestimate the amplitude of past changes. Our data also provide the first high-resolution estimates for dust fluxes on the northwest African margin between 15 and $20 \mathrm{ka}$.

We find that fluxes at $18-20 \mathrm{ka}$ are not substantially higher than in the Late Holocene. Dust fluxes reach maximum values during Heinrich Stadial 1 and the Younger Dryas and minimum levels during the end of the African Humid Period between 8 and $6 \mathrm{ka}$. Dust fluxes rise by a factor of $\sim 5$ from the AHP to the Late Holocene, suggesting that the radiative and biogeochemical impacts of low dust fluxes during the AHP could have been significant and are worthy of further exploration. Coretop dust fluxes match both the magnitude and meridional gradient of dust fluxes estimated from modern sediment trap studies.

Using a simple bioturbation model, we find that our records between 19 and $27^{\circ} \mathrm{N}$ are consistent with an abrupt, largeamplitude drop in dust inputs at the end of the YD at $11.8 \pm 0.2 \mathrm{ka}$ and an abrupt rise in dust fluxes at the end of the AHP at $4.9 \pm 0.2 \mathrm{ka}$, followed by a gradual rise in dust fluxes over the remainder of the Late Holocene.

Comparison of our dust records with opal fluxes measured in the same cores and with other regional records over the last $20 \mathrm{ka}$ indicates a consistent relationship between Atlantic meridional SST gradients and North African dust emissions, surface winds and precipitation. These quantitative, spatially resolved estimates of past changes in the North African dust plume lay the groundwork for further progress in understanding controls and feedbacks involving the world's largest dust source.

\section{Acknowledgments}

The authors would like to thank the crew, staff and scientists of R/V Oceanus cruise 437-7, and co-chief scientists Tim Eglinton and Thomas Wagner. Emily Dougan, Janet Fang, Martin Fleisher, Patricia Malone, Inka Meyer, Ben Purinton, Roseanne Schwartz and Ellen Ward provided important analytical assistance. We thank editor Gideon Henderson, Franco Marcantonio and two anonymous reviewers for comments that improved the manuscript. This work was supported by the NOAA Climate and Global Change Postdoctoral Fellowship Program (DM) and NSF awards OCE-1030784 (DM, PdM, GW), OCE-0402348 (PdM, TE).

\section{Appendix A. Supporting information}

Supplementary data associated with this article can be found in the online version at http://dx.doi.org/10.1016/j.epsl.2013.03.054.

\section{References}

Adkins, J., deMenocal, P., Eshel, G., 2006. The "African humid period" and the record of marine upwelling from excess 230 Th in Ocean Drilling Program Hole 658C. Paleoceanography 21, PA4203.

Anderson, R.F., Fleer, A.P., 1982. Determination of natural actinides and plutonium in marine particulate material. Anal. Chem. 54, 1142-1147.

Anderson, R.F., Rowe, G.T., Kemp, P.F., Trumbore, S., Biscaye, P.E., 1994. Carbon budget for the mid-slope depocenter of the Middle Atlantic Bight. Deep-Sea Res. Part II 41, 669-703.

Bard, E., Rostek, F., Turon, J., Gendreau, S., 2000. Hydrological impact of Heinrich events in the subtropical northeast Atlantic. Science 289, 1321-1324.

Berger, W.H., Heath, G.R., 1968. Vertical mixing in pelagic sediments. J. Mar. Res. 26, 134

Bory, A.J.M., Newton, P.P., 2000. Transport of airborne lithogenic material down through the water column in two contrasting regions of the eastern subtropical North Atlantic Ocean. Global Biogeochem. Cycles 14, 297-315.

Broccoli, A., Dahl, K., Stouffer, R., 2006. Response of the ITCZ to Northern Hemisphere cooling. Geophys. Res. Lett. 33, 1-4. http://dx.doi.org/10.1029/2005GL024546.

Brovkin, V., Bendtsen, J., Claussen, M., Ganopolski, A., Kubatzki, C., Petoukhov, V., Andreev, A., 2002. Carbon cycle, vegetation, and climate dynamics in the
Holocene: experiments with the CLIMBER-2 model. Global Biogeochem. Cycles 16, 1-20. http://dx.doi.org/10.1029/2001GB001662.

Chase, B., 2009. Evaluating the use of dune sediments as a proxy for palaeo-aridity: a southern African case study. Earth-Sci. Rev. 93, 31-45.

Chiang, J.C.H., Friedman, A.R., 2012. Extratropical cooling, interhemispheric thermal gradients, and tropical climate change. Annu. Rev. Earth .Planet. Sci. 40, 383-412.

Chiapello, I., Bergametti, G., Gomes, L., Chatenet, B., Dulac, F., Pimenta, J., Suares, E. S., 1995. An additional low layer transport of Sahelian and Saharan dust over the North-Eastern Tropical Atlantic. Geophys. Res. Lett. 22, 3191-3194.

Chiapello, I., Moulin, C., Prospero, J.M., 2005. Understanding the long-term variability of African dust transport across the Atlantic as recorded in both Barbados surface concentrations and large-scale Total Ozone Mapping Spectrometer (TOMS) optical thickness. J. Geophys. Res.-Atmos. 110, 1-9. http://dx doi.org/10.1029/2004JD005132.

Cole, J.M., Goldstein, S.L., deMenocal, P.B., Hemming, S.R., Grousset, F.E., 2009 Contrasting compositions of Saharan dust in the eastern Atlantic Ocean during the last deglaciation and African Humid Period. Earth Planet. Sci. Lett. 278, 257-266.

deMenocal, P.B., 1995. Plio-Pleistocene African climate. Science 270, 53-59.

deMenocal, P.B., Ortiz, J., Guilderson, T., Adkins, J., Sarnthein, M., Baker, L., Yarusinsky, M., 2000. Abrupt onset and termination of the African Humid Period: rapid climate responses to gradual insolation forcing. Quat. Sci. Rev. 19, 347-361.

deMenocal, P.B., Ruddiman, W.F., Pokras, E.M., 1993. Influence of high- and lowlatitude processes on African terrestrial climate: Pleistocene eolian records from equatorial Atlantic Ocean Drilling Program Site 663. Paleoceanography 8 209-242.

DeMott, P.J., 2003. African dust aerosols as atmospheric ice nuclei. Geophys. Res Lett. 30. http://dx.doi.org/10.1029/2003GL017410.

Doherty, O.M., Riemer, N., Hameed, S., 2012. Control of Saharan mineral dust transport to Barbados in winter by the Intertropical Convergence Zone over West Africa. J. Geophys. Res. 117, D19117.

Dupont, L.M., 1993. Vegetation zones in NW Africa during the Brunhes Chron reconstructed from marine palynological data. Quat. Sci. Rev. 12, 189-202.

Engelstaedter, S., Tegen, I., Washington, R., 2006. North African dust emissions and transport. Earth-Sci. Rev. 79, 73-100.

Engelstaedter, S., Washington, R., 2007a. Atmospheric controls on the annual cycle of North African dust. J. Geophys. Res.-Atmos. 112, 1-14. http://dx.doi.org/10. 1029/2006JD007195.

Engelstaedter, S., Washington, R., 2007b. Temporal controls on global dust emissions: the role of surface gustiness. Geophys. Res. Lett. 34, 1-14. http://dx.doi. org/10.1029/2006JD007195.

Evan, A.T., Foltz, G.R., Zhang, D., Vimont, D.J., 2011. Influence of African dust on ocean-atmosphere variability in the tropical Atlantic. Nat. Geosci. 4 $1-4$.

Evan, A.T., Mukhopadhyay, S., 2010. African dust over the northern tropical Atlantic: 1955-2008. J. Appl. Meteorol. Climatol. 49, 2213-2229.

Evan, A.T., Vimont, D.J., Heidinger, A.K., Kossin, J.P., Bennartz, R., 2009. The role of aerosols in the evolution of tropical North Atlantic Ocean temperature anomalies. Science 324, 778-781.

Fleisher, M.Q., Anderson, R.F., 2003. Assessing the collection efficiency of Ross Sea sediment traps using Th-230 and Pa-231. Deep-Sea Res. Part II 50 693-712.

Foerster, V., Junginger, A., Langkamp, O., Gebru, T., Asrat, A., Umer, M., Lamb, H.F., Wennrich, V., Rethemeyer, J., Nowaczyk, N., Trauth, M.H., Schaebitz, F., 2012 Climatic change recorded in the sediments of the Chew Bahir basin, southern Ethiopia, during the last 45,000 years. Quat. Int. 274, 25-37.

Gac, J., Kane, A., 1986. Le fleuve Senegal: I. Bilan hydrologique et flux continentaux de matieres particulaires a l'embouchure. Sci. Geol. Bull. 39, 99-130.

Gasse, F., 2000. Hydrological changes in the African tropics since the Last Glacial Maximum. Quat. Sci. Rev. 19, 189-211.

Glaccum, R.A., Prospero, J.M., 1980. Saharan aerosols over the tropical North Atlantic: mineralogy. Mar. Geol. 37, 295-321.

Goudie, A.S., Middleton, N.J., 2001. Saharan dust storms: nature and consequences. Earth-Sci. Rev. 56, 179-204.

Grousset, F., Parra, M., Bory, A., Martinez, P., Bertrand, P., Shimmield, G., Ellam, R. 1998. Saharan wind regimes traced by the $\mathrm{Sr}-\mathrm{Nd}$ isotopic composition of subtropical Atlantic sediments: Last Glacial maximum vs. today. Quat. Sci. Rev. 17, 395-409.

Hoelzmann, P., Jolly, D., Harrison, S.P., Laarif, F., Bonnefille, R., Pachur, H.J., 1998 Mid-Holocene land-surface conditions in northern Africa and the Arabian Peninsula: a data set for the analysis of biogeophysical feedbacks in the climate system. Global Biogeochem. Cycles 12, 35-51.

Holz, C., Stuut, J.-B., Henrich, R., Meggers, H., 2007. Variability in terrigenous sedimentation processes off northwest Africa and its relation to climate changes: inferences from grain-size distributions of a Holocene marine sediment record. Sediment. Geol. 202, 499-508.

Holz, C., Stuut, J.B.W., Henrich, R., 2004. Terrigenous sedimentation processes along the continental margin off NW Africa: implications from grain-size analysis of seabed sediments. Sedimentology 51, 1145-1154.

Huang, J., Zhang, C., Prospero, J.M., 2010. African dust outbreaks: a satellite perspective of temporal and spatial variability over the tropical Atlantic Ocean. J. Geophys. Res.-Atmos. 115, D05202, http://dx.doi.org/10.1029/ 2009JD012516. 
Inthorn, M., Mohrholz, V., Zabel, M., 2006. Nepheloid layer distribution in the Benguela upwelling area offshore Namibia. Deep Sea Res. Part I: Oceanogr. Res. Pap. 53, 1423-1438.

Itambi, A.C., von Dobeneck, T., Mulitza, S., Bickert, T., Heslop, D., 2009. Millennialscale northwest African droughts related to Heinrich events and DansgaardOeschger cycles: evidence in marine sediments from offshore Senegal. Paleoceanography 24, PA1205, http://dx.doi.org/10.1029/2007PA001570.

Jullien, E., Grousset, F., Malaize, B., Duprat, J., Sanchez-Goni, M., Eynaud, F., Charlier K., Schneider, R., Bory, A., Bout, V., Flores, J., 2007. Low-latitude "dusty events" vs. high-latitude "icy Heinrich events. Quat. Res. 68, 379-386.

Kalnay, E., Kanamitsu, M., Kistler, R., Collins, W., Deaven, D., Gandin, L., Iredell, M. Saha, S., White, G., Woollen, J., Zhu, Y., Chelliah, M., Ebisuzaki, W., Higgins, W., Janowiak, J., Mo, K.C., Ropelewski, C., Wang, J., Leetmaa, A., Reynolds, R., Jenne, R., Joseph, D., 1996. The NCEP/NCAR 40-year reanalysis project. Bull. Am. Meteorol. Soc. 77, 437-471

Kolla, V., Biscaye, P.E., Hanley, A.F., 1979. Distribution of quartz in Late Quaternary Atlantic sediments in relation to climate. Quat. Res. 11, 261-277.

Kröpelin, S., Verschuren, D., Lezine, A., Eggermont, H., Cocquyt, C., Francus, P., Cazet J., Fagot, M., Rumes, B., Russell, J., Darius, F., Conley, D., Schuster, M., von Suchodoletz, H., Engstrom, D., 2008. Climate-driven ecosystem succession in the Sahara: the past 6000 years. Science 320, 765-768.

Lam, P.J., Ohnemus, D.C., Marcus, M.A., 2012. The speciation of marine particulate iron adjacent to active and passive continental margins. Geochim. Cosmochim. Acta 80, 108-124.

Lancaster, N., Kocurek, G., Singhvi, A., Pandey, V., Deynoux, M., Ghienne, J., Lo, K., 2002. Late Pleistocene and Holocene dune activity and wind regimes in the western Sahara Desert of Mauritania. Geology 30, 991-994.

Laskar, J., Robutel, P., Joutel, F., Gastineau, M., Correia, A.C.M., Levrard, B., 2004. A long-term numerical solution for the insolation quantities of the Earth. Astron. Astrophys. 428, 261-285.

Lézine, A.-M., 2009. Timing of vegetation changes at the end of the Holocene Humid Period in desert areas at the northern edge of the Atlantic and Indian monsoon systems. C. R. Geosci. 341, 750-759.

Liu, Z., Wang Y., Gallimore, R., Gasse, F., Johnson, T., deMenocal, P., Adkins, J., Notaro, M. Prenticer, I.C., Kutzbach, J., Jacob, R., Behling, P., Wang, L., Ong, E., 2007. Simulating the transient evolution and abrupt change of Northern Africa atmosphere-oceanterrestrial ecosystem in the Holocene. Quat. Sci. Rev. 26, 1818-1837.

Liu, Z.Y., Wang, Y., Gallimore, R., Notaro, M., Prentice, I.C., 2006. On the cause of abrupt vegetation collapse in North Africa during the Holocene: climate variability vs. vegetation feedback. Geophys. Res. Lett. 33, 6.

McCave, I.N., 1983. Particulate size spectra, behavior, and origin of nepheloid layers over the Nova Scotian continental rise. J. Geophys. Res. 88, 7647-7666.

McGee, D., Broecker, W.S., Winckler, G., 2010. Gustiness: the driver of glacial dustiness? Quat. Sci. Rev. 29, 2340-2350.

Meyer, I., Davies, G.R., Stuut, J.-B.W., 2011. Grain size control on Sr-Nd isotope provenance studies and impact on paleoclimate reconstructions: an example from deep-sea sediments offshore NW Africa. Geochem. Geophys. Geosyst. 12, Q03005.

Miller, R.L., Tegen, I., Perlwitz, J., 2004. Surface radiative forcing by soil dust aerosols and the hydrologic cycle. J. Geophys. Res. 109, D04203.

Moore, C.M., Mills, M.M., Achterberg, E.P., Geider, R.J., Laroche, J., Lucas, M.I., Mcdonagh, E.L., Pan, X., Poulton, A.J., Rijkenberg, M.J.A., Suggett, D.J., Ussher, S.J., Woodward, E. M.S., 2009. Large-scale distribution of Atlantic nitrogen fixation controlled by iron availability. Nat. Geosci. 2, 867-871.

Mortlock, R., Froelich, P., 1989. A simple method for the rapid determination of biogenic opal in pelagic marine sediments. Deep-Sea Res. Part A-Oceanogr Res. Pap. 36, 1415-1426.

Mukhopadhyay, S., Kreycik, P., 2008. Dust generation and drought patterns in Africa from helium-4 in a modern Cape Verde coral. Geophys. Res. Lett. 35, L20820, http://dx.doi.org/10.1029/2008GL035722.

Mulitza, S., Heslop, D., Pittauerova, D., Fischer, H.W., Meyer, I., Stuut, J.-B., Zabel, M. Mollenhauer, G., Collins, J.A., Kuhnert, H., Schulz, M., 2010. Increase in African dust flux at the onset of commercial agriculture in the Sahel region. Nature 466 226-228.

Mulitza, S., Prange, M., Stuut, J.B., Zabel, M., von Dobeneck, T., Itambi, A.C., Nizou, J. Schulz, M., Wefer, G., 2008. Sahel megadroughts triggered by glacial slowdowns of Atlantic meridional overturning. Paleoceanography 23, PA4206, http: //dx.doi.org/10.1029/2008PA001637.

Neuer, S., Ratmeyer, V., Davenport, R., Fischer, G., Wefer, G., 1997. Deep water particle flux in the Canary Island region: seasonal trends in relation to long-term satellite derived pigment data and lateral sources. Deep-Sea Res. Part I-Oceanogr. Res. Pap. 44, 1451-1466.

Prospero, J.M., Ginoux, P., Torres, O., Nicholson, S.E., Gill, T.E., 2002. Environmenta characterization of global sources of atmospheric soil dust identified with the Nimbus 7 Total Ozone Mapping Spectrometer (TOMS) absorbing aerosol product. Rev. Geophys. 40, 1-31. http://dx.doi.org/10.1029/2000RG000095.

Prospero, J.M., Lamb, P.J., 2003. African droughts and dust transport to the Caribbean: climate change implications. Science 302, 1024-1027.

Rasmussen, S.O., Andersen, K.K., Svensson, A.M., Steffensen, J.P., Vinther, B.M. Clausen, H.B., Siggaard-Andersen, M.-L., Johnsen, S.J., Larsen, L.B., Dahl-Jensen, D., Bigler, M., Röthlisberger, R., Fischer, H., Goto-Azuma, K., Hansson, M.E., Ruth, U., 2006. A new Greenland ice core chronology for the last glacial termination. J. Geophys. Res. 111, D06102, http://dx.doi.org/10.1029/2005JD006079.

Ratmeyer, V., Fischer, G., Wefer, G., 1999. Lithogenic particle fluxes and grain size distributions in the deep ocean off northwest Africa: implications for seasonal changes of aeolian dust input and downward transport. Deep-Sea Res. Part I-Oceanogr. Res. Pap. 46, 1289-1337.
Renssen, H., Brovkin, V., Fichefet, T., Goosse, H., 2003. Holocene climate instability during the termination of the African Humid Period. Geophys. Res. Lett. 30, 1-4. http://dx.doi.org/10.1029/2002GL016636.

Ridley, D.A., Heald, C.L., Ford, B., 2012. North African dust export and deposition: a satellite and model perspective. J. Geophys. Res.-Atmos. 117, D02202, http: //dx.doi.org/10.1029/2011JD016794.

Romero, O.E., Kim, J.H., Donner, B., 2008. Submillennial-to-millennial variability of diatom production off Mauritania, NW Africa, during the last glacial cycle. Paleoceanography 23, PA3218, http://dx.doi.org/10.1029/2008PA001601.

Roskin, J., Tsoar, H., Porat, N., Blumberg, D.G., 2011. Palaeoclimate interpretations of Late Pleistocene vegetated linear dune mobilization episodes: evidence from the northwestern Negev dunefield, Israel. Quat. Sci. Rev. 30, 3364-3380.

Sarnthein, M., Tetzlaff, G., Koopmann, B., Wolter, K., Pflaumann, U., 1981. Glacial and interglacial wind regimes over the eastern subtropical Atlantic and NorthWest Africa. Nature 293, 193-196.

Schepanski, K., Tegen, I., Todd, M.C., Heinold, B., Bonisch, G., Laurent, B., Macke, A., 2009. Meteorological processes forcing Saharan dust emission inferred from MSG-SEVIRI observations of subdaily dust source activation and numerical models. J. Geophys. Res.-Atmos. 114, 1-18. http://dx.doi.org/10.1029/ 2008jd010325.

Shakun, J.D., Clark, P.U., He, F., Marcott, S.A., Mix, A.C., Liu, Z., Otto-Bliesner, B., Schmittner, A., Bard, E., 2012. Global warming preceded by increasing carbon dioxide concentrations during the last deglaciation. Nature 484, 49-54.

Shanahan, T.M., Overpeck, J.T., Wheeler, C.W., Beek, J.W., Pigati, J.S., Talbot, M.R., Scholz, C.A., Peck, J., King, J.W., 2006. Paleoclimatic variations in West Africa from a record of late Pleistocene and Holocene lake level stands of Lake Bosumtwi, Ghana. Palaeogeogr. Palaeoclimatol. Palaeoecol. 242, 287-302.

Skonieczny, C., Bory, A., Bout-Roumazeilles, V., Abouchami, W., Galer, S.J.G., Crosta, X., Diallo, A., Ndiaye, T., 2013. A three-year time series of mineral dust deposits on the West African margin: sedimentological and geochemical signatures and implications for interpretation of marine paleo-dust records. Earth Planet. Sci. Lett. 364, 145-156.

Skonieczny, C., Bory, A., Bout-Roumazeilles, V., Abouchami, W., Galer, S.J.G., Crosta, X., Stuut, J.-B., Meyer, I., Chiapello, I., Podvin, T., Chatanet, B., Diallo, A., Ndiaye, T., 2011. The 7-13 March 2006 major Saharan outbreak: multiproxy characterization of mineral dust deposited on the West African margin. J. Geophys. Res. 116, D18210.

Stuut, J.-B., Zabel, M., Ratmeyer, V., Helmke, P., Schefu, E., Lavik, G., Schneider, R, 2005. Provenance of present-day eolian dust collected off NW Africa. J. Geophys. Res. D: Atmos. 110, 1-14.

Sun, D., 2004. Monsoon and westerly circulation changes recorded in the late Cenozoic aeolian sequences of Northern China. Global Planet. Change 41, 63-80.

Swezey, C., 2001. Eolian sediment responses to late Quaternary climate changes: temporal and spatial patterns in the Sahara. Palaeogeogr. Palaeoclimatol. Palaeoecol. 167, 119-155.

Tierney, J.E., Russell, J.M., Huang, Y., Damste, J.S.S., Hopmans, E.C., Cohen, A.S., 2008. Northern hemisphere controls on tropical southeast African climate during the past 60,000 years. Science $322,252-255$.

Tjallingii, R., Claussen, M., Stuut, J.-B.W., Fohlmeister, J., Jahn, A., Bickert, T., Lamy, F., Rohl, U., 2008. Coherent high- and low-latitude control of the northwest African hydrological balance. Nat. Geosci. 1, 670-675.

Tsoar, H., 2005. Sand dunes mobility and stability in relation to climate. Physica A: Stat. Mechan. Appl. 357, 50-56.

Vellinga, M., Wood, R.A., 2002. Global climatic impacts of a collapse of the Atlantic thermohaline circulation. Clim. Change 54, 251-267.

Wang, Y., Mysak, L.A., Wang, Z.M., Brovkin, V., 2005. The greening of the McGill paleoclimate model. Part II: simulation of Holocene millennial-scale natural climate changes. Clim. Dyn. 24, 481-496.

Warren, A., Chappell, A., Todd, M., Bristow, C., Drake, N., Engelstaedter, S., Martins, V., M'Bainayel, S., Washington, R., 2007. Dust-raising in the dustiest place on Earth. Geomorphology 92, 25-37.

Weaver, P.P.E., Rothwell, R.G., Ebbing, J., Gunn, D., Hunter, P.M., 1992. Correlation, frequency of emplacement and source directions of megaturbidites on the Madeira Abyssal-Plain. Mar. Geol. 109, 1-20.

Weldeab, S., Lea, D.W., Schneider, R.R., Andersen, N., 2007. Centennial scale climate instabilities in a wet early Holocene West African monsoon. Geophys. Res. Lett. 34, L24702, http://dx.doi.org/10.1029/2007GL031898.

Weltje, G.J., 1997. End-member modeling of compositional data: numericalstatistical algorithms for solving the explicit mixing problem. Math. Geol. 29, 503-549.

Wien, K., Kolling, M., Schulz, H.D., 2007. Age models for the Cape Blanc Debris Flow and the Mauritania Slide Complex in the Atlantic Ocean off NW Africa. Quat. Sci. Rev. 26, 2558-2573.

Williams, 2008. Comment on "Atmospheric controls on the annual cycle of North African dust" by S. Engelstaedter and R. Washington. J. Geophys. Res. 113, D23109, http://dx.doi.org/10.1029/2008JD009930.

Wong, S., Dessler, A.E., Mahowald, N.M., Colarco, P.R., da Silva, A., 2008. Long-term variability in Saharan dust transport and its link to North Atlantic sea surface temperature. Geophys. Res. Lett. 35, L07812, http://dx.doi.org/10.1029/ 2007GL032297.

Yizhaq, H., Ashkenazy, Y., Tsoar, H., 2009. Sand dune dynamics and climate change: a modeling approach. J. Geophys. Res. 114, F01023. 
Yoshioka, M., Mahowald, N.M., Conley, A.J., Collins, W.D., Fillmore, D.W., Zender, C.S., Coleman, D.B., 2007. Impact of desert dust radiative forcing on Sahel precipitation: relative importance of dust compared to sea surface temperature variations, vegetation changes, and greenhouse gas warming. J. Clim. 20, 1445-1467.

Zarriess, M., Mackensen, A., 2010. The tropical rainbelt and productivity changes off northwest Africa: a 31,000-year high-resolution record. Mar. Micropaleontol. 76, 76-91.
Zobeck, T., Gill, T., Popham, T., 1999. A two-parameter Weibull function to describe airborne dust particle size distributions. Earth Surf. Processes Landforms 24, 943-955.

Zuhlsdorff, C., Wien, K., Stuut, J.B.W., Henrich, R., 2007. Late Quaternary sedimentation within a submarine channel-levee system offshore Cap Timiris, Mauritania. Mar. Geol. 240, 217-234. 